NBER WORKING PAPER SERIES

\title{
FRICTIONS AND TAX-MOTIVATED HEDGING: AN EMPIRICAL EXPLORATION OF PUBLICLY-TRADED EXCHANGEABLE SECURITIES
}

\author{
William M. Gentry \\ David M. Schizer \\ Working Paper 9243 \\ http://www.nber.org/papers/w9243
NATIONAL BUREAU OF ECONOMIC RESEARCH
1050 Massachusetts Avenue
Cambridge, MA 02138 \\ October 2002
}

\begin{abstract}
We thank Jon Kaufman, Craig Lee, Tommy Ng, and Benjamin Ornstein for excellent research assistance. We are grateful to Mary Ellen Carter, Mihir Desai, Mary Margaret Frank, Charles Jones, Meredith Wolf Schizer, Doug Shackelford, and workshop participants at Columbia University, the National Bureau of Economic Research, and the University of North Carolina's Tax Symposium for helpful comments. Gentry gratefully acknowledges financial support from the National Bureau of Economic Research. Schizer gratefully acknowledges financial support from the Milton Handler fellowship for summer research at Columbia Law School. The views expressed herein are those of the authors and not necessarily those of the National Bureau of Economic Research.

(C) 2002 by William M. Gentry and David M. Schizer. All rights reserved. Short sections of text, not to exceed two paragraphs, may be quoted without explicit permission provided that full credit, including (C) notice, is given to the source.
\end{abstract}


Frictions and Tax-Motivated Hedging: An Empirical Exploration of Publicly-Traded

Exchangeable Securities

William M. Gentry and David M. Schizer

NBER Working Paper No. 9243

October 2002

JEL No. G30, G14, H25

\section{$\underline{\text { ABSTRACT }}$}

As financial engineering becomes more sophisticated, taxing income from capital becomes increasingly difficult. A crucial issue for tax policymakers, then, is the ease - or difficulty - of implementing tax-advantaged transactions We offer the first empirical study of a high profile strategy known as "tax-free hedging," which offers economic benefits of a sale without triggering tax. We explore one method of hedging, in which the taxpayer issues publicly-traded exchangeable securities, known by acronyms such as DECS and PHONES. We focus on such offerings between 1992 and 2001, identifying 61 transactions that account for \$24 billion in proceeds. Using these publicly-available data, we offer empirical evidence about various frictions that might discourage taxpayers from hedging with exchangeable securities. In so doing, we shed light on why taxpayers might prefer to hedge through private "over-the-counter" transactions with derivatives dealers. The main reason is that an offering of exchangeable securities is announced in advance and implemented all at once, triggering an almost four percent decline in the underlying stock price before the hedge is implemented.

William M. Gentry 602 Uris Hall

Graduate School of Business

Columbia University

New York, NY 10027

and NBER

wmg6@columbia.edu
David M. Schizer

619 Jerome Greene Hall

Box E-13

Columbia Law School

New York, NY 10027

dschiz@law.columbia.edu 


\section{Frictions and Tax-Motivated Hedging: An Empirical Exploration of Publicly-Traded Exchangeable Securities}

As financial engineering becomes more sophisticated, taxing income from capital becomes increasingly difficult (see, e.g., Bradford (1995) and Warren (1993)). A crucial issue for tax policymakers, then, is the ease - or difficulty - of implementing tax-advantaged transactions (see, e.g., Schizer (2001)). Yet given the inherent secrecy of sophisticated tax planning, the necessary data is usually unavailable. In an effort to shed light on high-end tax planning, we offer the first empirical study of a high profile strategy known as "tax-free hedging," which offers economic benefits of a sale without triggering tax. ${ }^{1}$ We explore one method of hedging, in which the taxpayer issues publicly-traded exchangeable securities, known by acronyms such as DECS and PHONES (hereinafter "exchangeable securities"). ${ }^{2}$ We focus on such offerings between 1992 and 2001, identifying 61 transactions that account for \$24 billion in proceeds. Using these publicly-available data, we offer empirical evidence about various nontax costs or so-called "frictions" that discourage taxpayers from hedging with exchangeable securities. In so doing, we show why these transactions can prove costly. Relatedly, we explain why taxpayers often prefer to hedge through a different method - private "over-the-counter" transactions with derivatives dealers - a preference that, until now, has been suggested only through anecdotal evidence.

Some frictions, including fees to an investment bank, also burden over-the-counter transactions (and, for that matter, taxable block sales). Yet at least two frictions burden exchangeable securities but not over-the-counter deals. First, with a public offering, the taxpayer must announce the hedge to the market in advance, thereby precipitating a decline in the underlying stock price before the hedge is implemented. Likewise, a public offering typically is implemented all at once, and thus causes price pressure on the underlying stock. Over-the- counter deals generally can avoid these costs because they are not announced in advance and are executed in stages. Thus, we find that the announcement of an exchangeable offering is associated with a -1.62 percent average abnormal return in the underlying stock, measured on the announcement date and

\footnotetext{
1 See, e.g., Paul (1996), Schenk (1995), and Weisbach, (1997).

${ }^{2}$ See Schizer (2001).
} 
the following two trading days; however, this effect is imprecisely estimated. Later, when the hedging security actually is issued, there is a -3.33 percent average abnormal return in the underlying stock (i.e., over the two days before the security is issued) that is statistically different from zero at the 95 percent confidence level.

Second, the complexity and relative illiquidity of exchangeable securities may force the taxpayer to issue them at a discount, a cost that should not burden over-the-counter transactions because securities dealers have a high tolerance for complexity and illiquidity. If generous pricing must be offered, arbitrageurs can be expected to capitalize on it and, ultimately, to trade it away. On the other hand, discounted pricing may in fact be unnecessary. Anecdotal evidence suggests that certain clienteles, including hedge funds, actually prefer exchangeable securities to the underlying stock. While our evidence on this question is not clear cut, our finding is more consistent with the hypothesis that issuers do not offer discounts (or, at least, discounts that are corrected in the short term).

In general, our findings suggest that public exchangeable securities pose less of a threat to the tax base than private over-the-counter transactions. Likewise, given the costliness of public transactions, taxpayers will not always turn to them if private transactions become more difficult, for instance, due to a targeted tax reform aimed only at private transactions. Yet some substitutions are likely. As (limited) support for the prediction that some substitutions will occur, we find that when a publicly-traded taxpayer announces an exchangeable securities offering, the taxpayer's stock price generally rises. The implication is that in the deals in our sample - and presumably in at least some other deals as well - the market believes that the tax savings or other benefits outweigh the costs.

The paper proceeds as follows. After considering instances in which taxpayers can acquire a large appreciated block of stock, Part I outlines various ways of disposing of this stock, of which some trigger an immediate tax and some do not. Part II focuses on exchangeable securities, describing our data sample and offering summary statistics. Part III analyzes and quantifies important frictions that burden exchangeable securities, while also mentioning frictions that burden the other disposition methods outlined in Part I. Part IV examines announcement effects on the 
issuers' stock and contrasts these effects with the announcement effects on other methods of raising capital, especially those related to disposing of assets. Part V is the conclusion.

\section{Alternative Disposition Strategies}

We begin by explaining the scenario that prompts taxpayers to issue exchangeable securities. After surveying various ways that taxpayers acquire large appreciated blocks of stock, this Part describes alternative disposition strategies for taxpayers that no longer want this investment. This Part concludes by flagging tax issues on which there is legal uncertainty.

\section{I.A. Origin of Appreciated Stock Positions}

Taxpayers acquire large blocks of stock in a number of ways. An individual might do so as a founder or senior executive of a firm, or as a successful passive investor. Firms also acquire stock in unrelated firms. In a tax-free reorganization, for instance, the taxpayer might sell a division to an acquirer in return for acquirer stock. Or the taxpayer might sell or spin off the majority of a subsidiary, while retaining a "stub." Alternatively, the taxpayer might purchase a stake in a start-up through a venture capital investment or joint venture. ${ }^{3}$

These large stock positions often are highly appreciated. The firm may have paid very little to acquire the stock (e.g., in a start-up investment). Or the firm may have acquired the stock in a reorganization, such that the stock basis derives from a real asset that was subject to tax depreciation. These acquisitions may have occurred years earlier and, during the bull market of the 1990s, stock appreciation was rapid, especially for high-technology firms.

However the taxpayer acquired the appreciated stock, the degree of taxpayer control over the portfolio investment will vary, as will the size of the taxpayer's stake. Yet all the scenarios are similar in an important way: At some point, the taxpayer will want to sell. The taxpayer may believe the portfolio investment has peaked in value, or may need cash for a more promising opportunity. Individuals will also want to diversify, a motivation that (agency costs aside) should be less important for corporate taxpayers since the firm's shareholders can diversify on their own.

\footnotetext{
${ }^{3}$ For examples of these various ways of acquiring large blocks of stock that are relevant for our sample, see Appendix A, which lists the deals in our sample and offers details about how the taxpayer acquired the block of stock.
} 


\section{I.B. Taxable Sale}

In these situations, the most straightforward response is simply to sell the position. If only a small percentage of the overall float is involved, the taxpayer might simply place a sell order with a broker, just as a retail investor would do. If the position is large, portions of the position can be sold in this manner over time, a strategy we call a "serial sale." To sell a large position all at once, the taxpayer can hire an investment bank to execute in a block sale.

These various sales implicate different disclosure requirements and costs, as discussed below in Part III. Yet they share one important cost: They are all taxable. Thus, individuals pay tax at the applicable combined federal and state capital gains tax rate. By selling, individuals also forfeit the opportunity to attain a step-up in basis at death that would eliminate the income tax on the unrealized capital gain. While the latter factor obviously is not a concern to corporate taxpayers, they typically face higher tax rates on capital gains (generally a federal tax rate of 35 percent) than individuals face. This tax is due even if the firm is not otherwise profitable, since ordinary losses (i.e., from operations of the firm's business) cannot offset capital gain. Only a firm with otherwise unused capital losses is indifferent to this tax liability.

\section{I.C. Tax-Deferred Alternatives}

Some investors, then, that will have business reasons to sell appreciated stock, but tax reasons not to do so. These investors might favor strategies that offer the benefits of a sale, such as cash proceeds and insulation from risk, without triggering a current capital gains tax. Obviously, a "tax free" reorganization offers tax deferral and a change in the taxpayer's investment (albeit no cash, assuming tax is deferred), but we assume that the type of position owned by the taxpayer cannot qualify for such a reorganization.

Tax advisors have developed various "hedging" transactions in which the taxpayer retains title and control over the appreciated asset, while transferring the economic return through a separate contractual arrangement. Short sales "against the box" are an old version of this strategy, while derivative securities such as swaps and collars offer more modern variations. Until 1997, taxpayers could transfer all the economic exposure of a publicly-traded stock, receive sale proceeds, 
and not trigger current capital gains tax. Tax would be deferred until the taxpayer physically delivered the property to settle the hedge.

After a widely publicized short sale against the box, Congress responded in 1997 with the constructive sale rule of Internal Revenue Code Section 1259. Technical details aside, this rule imposes a current tax if the hedge is too perfect, but allows taxpayers to defer their tax as long as the hedge is sufficiently imperfect. The key question is whether the hedge transfers "substantially all" of the risk of loss and opportunity for gain in the appreciated asset. Thus, the typical way to avoid section 1259 is to retain some exposure to the hedged asset's return - in other words, to use a partial hedge. For example, if an asset is worth $\$ 100$, the taxpayer can accept risk of loss from $\$ 100$ to $\$ 95$ (by buying a put at $\$ 95$ ), while retaining opportunity for gain from $\$ 100$ to $\$ 115$ (by selling a call at \$115); such a combination of a put and a call is known as a collar. Practitioners generally believe that such a transaction does not trigger a current tax (see generally Schizer (1998)).

\section{I.C.1. Issuance of Exchangeable Securities}

The core feature of a tax-deferred hedge is that the taxpayer transfers most, but not all, of the appreciated asset's economic return to a hedging counterparty. One source of hedging counterparties is the public market. Thus, in the transactions that we study, the taxpayer issues an exchangeable security to public investors (or, in some cases, to institutional investors in a private placement). To serve as a close substitute for a sale, this exchangeable security has a feature that distinguishes it from "classic" exchangeable debt that has been studied by others: The holder, rather than the issuer, bears risk of loss in the underlying security. ${ }^{4}$

For example, assume that a firm ("Corporation") owns one million shares of stock of the Portfolio Corporation (the "Stock"), a 5\% interest in Portfolio Corporation (with the rest held by public shareholders). Corporation’s cost basis is $\$ 20$ per share, and the Stock price is now $\$ 100$.

\footnotetext{
${ }^{4}$ One type of security in our sample, PHONES, resembles classic exchangeable debt in that it offers investors principal protection. But the very long term of PHONES - thirty years, compared with the five or ten year term that is typical of classic exchangeable debt - renders this principal protection economically insignificant. In substance, then, PHONES do expose the holder to risk of loss in the underlying security. For a discussion of PHONES, see infra Part I.C.4

Studies of classic exchangeable debt (see Barber (1993) and Ghosh et. al. (1990)) have concluded that its use is not tax motivated. This is not surprising since, in leaving the issuer with full risk of loss on the underlying stock, these deals are not close substitutes for a taxable sale. Furthermore, these old exchangeable securities were developed during a bear market in which fewer firms had appreciated stock.
} 
On January 1, 2002, Corporation issues one million securities ("Debt Exchangeable for Common Stock" or "DECS") to investors ("Holders") for $\$ 100 .^{5}$ Through the DECS, Corporation transfers most of the economic return in the Stock to Holders, while retaining some opportunity for gain in order to avoid a constructive sale. To compensate Holders for receiving less than all the opportunity for gain, Corporation makes a periodic payment exceeding the dividend on the Stock. Specifically, assuming the Stock pays no dividends, Holders receive annual interest payments of $6 \%$ during the five-year term of the DECS. At maturity, Holders receive a number of shares of Stock (the "Exchange Ratio") that depends on the trading price of the Stock at maturity. The Exchange Ratio is determined as follows:

\begin{tabular}{|c|c|c|}
\hline$\underline{\text { Stock Price at Maturity }}$ & $\underline{\text { Exchange Ratio }}$ & $\underline{\text { Cash Equivalent Amount }}$ \\
\hline Less than $\$ 100$ & 1.0 share & Value of one share of Stock \\
\hline $\begin{array}{l}\text { From and including } \$ 100 \text { to } \\
\text { and including } \$ 120\end{array}$ & 1.0 share to .833 shares & $\$ 100$ \\
\hline Above $\$ 120$ & .833 shares & $\begin{array}{l}\$ 100 \text { plus } 83 \% \text { of the excess of } \\
\text { the value of one share of Stock } \\
\text { over } \$ 120 \text {. }\end{array}$ \\
\hline
\end{tabular}

The effect is to transfer to Holders the full risk of loss in the Stock. If the Stock is worth $\$ 15$, then Holders will receive $\$ 15$ (whether in stock or cash). On the other hand, as the Stock price rises from $\$ 100$ to $\$ 120$, Holders do not share in that appreciation. DECS yield more than $\$ 100$ at maturity only if the Stock appreciates above \$120. At that point, Holders enjoy $83 \%$ of increases. For instance, if the stock price rises to $\$ 220$, the Holder will receive $\$ 183$. Since Corporation retains all appreciation from $\$ 100$ to $\$ 120$, and $17 \%$ of the rest, tax lawyers generally believe that issuance of a DECS with these terms does not trigger capital gains tax.

In the above example, the taxpayer is a corporation. It is more difficult (and thus less common) for individuals to use the public markets for hedging, since, unlike corporations, individuals are not able to issue securities under their own names. Instead, individuals form a trust to serve as an intermediary that issues the securities. The individual then enters into a hedging contract with the

5 "DECS" is a service mark of Salomon Brothers. Other investment banks market similar products but use other acronyms, such as STRYPES, ACES, SAILS, MEDS, PEPS, and PERCS. 
trust (with terms that resemble the DECS described above). ${ }^{6}$ The trust, in turn, issues a similar security to the public. This structure imposes fixed costs that do not arise for corporations, since a trust must be established and maintained; in contrast, corporate issuers already are equipped to issue public securities.

\section{I.C.2. Over-the-Counter Alternative}

Instead of hedging through the public markets, taxpayers can enter into private transactions with securities dealers involving equity swaps, prepaid forward contracts, or collars. As long as these hedges are structured to leave the taxpayer with sufficient exposure to the underlying stock, they do not trigger a constructive sale. Frictions arise in these transactions as well, but this study does not address them because public data are not available.

Anecdotal evidence suggests that these transactions are common, and that the volume is considerably larger than the volume of public deals for which data are available. For instance, Liberty Media Corporation's April 2002 Annual Report offers a rare glimpse of a firm's over-thecounter hedging. In addition to issuing exchangeable securities to hedge $\$ 3.2$ billion of stock (in transactions that are in our sample), Liberty reports that it also hedged an additional $\$ 9.2$ billion of stock through over-the-counter deals. Unfortunately, this detailed report is atypical.

Notwithstanding data limitations, our analysis in Part III sheds light on the question of why taxpayers might prefer over-the-counter deals to exchangeable securities. One factor is that the private nature of the over-the-counter transactions is itself valuable, helping the taxpayer "sell" the appreciated stock at a higher price. A second factor is that public investors might demand a premium for holding complex and illiquid hedging securities, while securities dealers do not.

\footnotetext{
${ }^{6}$ One difference is that the individual generally compensates the trust for time value - not with a periodic payment - but by accepting a discount on the proceeds received. For instance, if the current price of the underlying stock is $\$ 100$, the trust is likely to pay only, say, $\$ 82$. Meanwhile, the trust will still raise $\$ 100$ from public investors, and will use the remaining $\$ 18$ to buy Treasury strips that fund a periodic payment to investors.

${ }^{7}$ For instance, an "affiliate," including an officer, director, or shareholder that owns more than ten percent of the firm, may have to hold the stock for more than a year before hedging (e.g., if the stock was acquired in a private placement) and the securities dealer that executes the transaction may have to comply with the volume and manner of sale limitations of Rule 144 (i.e., on short sales with which the dealer hedges its own exposure on the derivative). There are also securities law constraints on nonaffiliates who hedge stock received in a private placement, but these constraints are modest. Small investors generally cannot use the over-the-counter derivatives market because of the commodities laws. For a discussion of these and other frictions, see Schizer (2001) and Schizer (2000c).
} 


\section{I.C.3. The Economic Value of Tax Deferral}

While the financial press and even firm's annual reports claim that the exchangeable securities provide a tax-efficient form of financial management, one would like a systematic calculation of the potential tax savings from hedging rather than selling a position. ${ }^{8}$ Estimating the basis of the issuers is complicated by the various ways in which the investors acquire their position, as discussed in Part I.A.

Appendix A provides brief statements about how the issuers acquired their positions. Examples of typical transactions illustrate the difficulties in establishing the unrealized capital gain. For example, Kerr-McGee acquired its stock in Devon Energy in 1996 in exchange for its North American onshore oil and gas fields, presumably in a tax-free reorganization; in 1999, Kerr-McGee issued DECS based on its shares in Devon Energy. Kerr-McGee's tax basis in these shares would be its carry-over basis from it oil properties, a number that is not disclosed but is likely to be quite low (e.g., due to tax depreciation). For the trust-based deals, the Snyder STRYPES Trust is representative. Daniel Snyder and various family members backed the trust whose securities were based on shares of Snyder Communications, of which Daniel Snyder was founder and chief executive officer; as founder of a highly successful company, he likely had a low basis in his shares.

While we could not find systematic data on tax basis, we found several examples that confirm the claim that the issuer had a large capital gain. For example, the Tribune Company's 1991 investment of $\$ 5$ million in America Online was a tremendous success, representing over half of the shares on which Tribune's issuance of $\$ 1.1$ billion of PHONES in 1999 was based; thus, almost the entire value of this position was a capital gain. By comparison, Tribune's DECS based on its Learning Company stock are related to an investment with more pedestrian performance. In 1993, Tribune acquired Compton’s from Encyclopedia Britannica for \$57 million in cash; in 1995, it acquired shares in the Learning Company in exchange for its equity in Compton's. In 1998, Tribune raised \$128.5 million in a DECS offering based on its position in the Learning Company.

\footnotetext{
${ }^{8}$ Liberty Media's 2002 Annual Report extols the benefits of both public and over-the-counter transactions (page 6): "We were particularly active in the financial management arena in 2001. As we were anticipating a potential decline in public company stock prices, we took aggressive steps during the year to protect some of our public stock holdings. We used financial instruments to limit our downside risk in these holdings and to extract liquidity from non-strategic investments in a tax-efficient manner."
} 
Using the $\$ 57$ million as a rough estimate of Tribune's basis in the Learning Company (various intracompany transactions between 1993 and 1998 could have affected this basis), the basis was only 44 percent of the total value of the asset. In general, the other examples that we found suggest appreciation between these two examples, such that tax deferral is likely to be a key feature of these transactions.

The size of the gain is only one of the inputs necessary for calculating the value of tax deferral. In addition, the applicable tax rate at the issue date (when the stock would have been sold) and when the security is settled (if it is settled with stock) will affect the tax savings. A firm's tax rate on capital gains is also difficult to estimate. The fact that a firm has net operating losses, for instance, affects only its tax rate on ordinary income, but not its tax rate on capital gain. The term of the security, the firm's discount rate and various aspects of the security affect the amount of tax savings generated by hedging rather than selling the position. As a simplistic benchmark for the potential tax savings at stake in these transactions, Table 1 provides the present value of the tax savings from tax deferral under some simple assumptions. The corporate tax rate is assumed to be 35 percent. Various assumptions are made about the duration of the deferral (three, five, ten, and thirty years), the tax basis (zero, 25 and 50 percent of the total value), and discount rate (five and ten percent). Each cell offers the tax savings' present value as a percentage of the position's value. The length of maturity is the most important determinant of the tax deferral's value. For the shorter duration instruments, the value of the tax savings is generally less than ten percent of the value of the security; however, for a 30-year instrument, the value of tax deferral may be over 20 percent of the value of the asset.

These calculations belie many technical details that complicate the analysis of tax benefits. For example, issuers have the option of settling in cash and possibly continuing to defer tax by issuing another security or holding the position unhedged. In addition, the issuer makes periodic payments and also retains some exposure to risk, each of which affects the issuer's overall tax liability. Periodic payments - through which the issuer purchases the ability to share in further gains on the stock - reduce the issuer's tax liability. ${ }^{9}$ On the other hand, since the issuer retains some

\footnotetext{
${ }^{9}$ Either they are deductible or they must be capitalized into the basis of the stock, depending on application of the straddle rules. See Part I.C.4.
} 
opportunity for gain, subsequent share price appreciation can increase the issuer's tax liability. ${ }^{10}$ These complications highlight that precise calculations of tax savings are difficult even if complete data were available. Nonetheless, the calculations in Table 3 provide the general magnitude of the tax savings from exchangeable securities relative to selling a position.

\section{I.C.4. Tax Uncertainty}

Of course, taxpayers themselves will know how much they stand to gain from deferring the tax unless there is uncertainty about whether the tax actually can be deferred - that is, about whether hedging transactions actually avoid triggering capital gains tax. Such uncertainty would deter marginal transactions. Yet the tax bar generally is very confident about hedging transactions in which the taxpayer retains the first 20 percent of appreciation in the underlying property, like a DECS transaction or the typical over-the-counter transaction. It is doubtful that many of these transactions have been deterred by tax uncertainty.

A more aggressive variation of public securities has been the subject of uncertainty, though. With a "PHONES" security, the issuer does not keep any opportunity for gain on 95 percent of the hedged shares; instead, the issuer nominally keeps the full risk of loss - the reason why a constructive sale arguably is not triggered. ${ }^{11}$ Yet this claim is aggressive because the security does not mature for thirty years, and so the present value of this risk of loss is insignificant. While there is uncertainty about whether this transaction "works," conservative taxpayers remain free to use the safer "DECS" structure.

\footnotetext{
${ }^{10}$ As a simple example, return to our numerical example of a DECS contract from Part I.C.1. The issuer has a capital gain of $\$ 80$ per share for each of 1 million shares. Assuming that the share price at expiration is $\$ 90$ and the issuer elects to settle the contract with stock, the issuer will recognize a capital gain of $\$ 80$ per share ( $\$ 80$ million in total) at maturity because it received $\$ 100$ million for the stock for which it paid $\$ 20$ million, despite the fact that if it had not hedged and had sold the stock at the maturity, the gain would have only been $\$ 70$ million. Alternatively, assume the stock price appreciates to $\$ 150$ per share at maturity. The issuer can settle the contract by delivering 833,333 shares to the holders. Its tax basis in these shares would be $\$ 16.67$ million. The gain associated with these shares would be the $\$ 100$ million received at the issuance of the DECS less this tax basis, which is $\$ 83.33$ million. In addition, the issuer still holds 166,667 shares with a tax basis of \$20 per share. The unrealized capital gain on these shares is $\$ 21.67$ million. Note that any increase in the issuer's tax liability is offset, from the government's perspective, by a reduction in the holder's tax liability. For instance, if the stock price declines - such that the hedge preserved the issuer's profit (and thus inflated the issuer's tax liability) - the holder will have a corresponding capital loss.

${ }^{11}$ PHONES is a service mark of Merrill Lynch. Other similar products include PRIZES and ZONES.
} 
Finally, there has been uncertainty about a separate tax question. Typically, taxpayers combine their hedging transaction with a financing, in that they receive cash (the equivalent of sale proceeds) at the same time that they transfer the economic return in the hedged asset. In return for this cash, taxpayers must compensate their hedging counterparty (whether it is a public investor or an investment bank) with a payment that is the economic equivalent of interest. It is not clear whether this interest expense is deductible. In part, the question turns on whether the hedge is structured to qualify as debt for tax purposes. While there is some uncertainty on the issue, DECS and PHONES generally are thought to satisfy this condition, but trust structures do not. ${ }^{12}$ Furthermore, under the tax straddle rules, the debt must not be too closely related to the hedge. ${ }^{13}$ Until recently (and throughout the time period for which we have data), many tax advisors believed that this test could be satisfied as long as the hedged asset was not purchased with proceeds from the debt, and was not pledged to secure the debt (see Schizer (2000b)). Some tax advisors were more conservative on this issue. Since 2000, though, a proposed regulation generally has disallowed the interest deduction in all DECS and PHONES, requiring this expense to be capitalized into the basis of the hedged stock. ${ }^{14}$

\section{Sample Selection and Summary Statistics}

We create a sample of transactions having four characteristics. First, the issuer issues an exchangeable security with a payoff that depends on the stock of another company. Second, the underlying stock is publicly traded. Third, the issuer continues to own the underlying stock. This requirement eliminates transactions in which investment banks issue exchangeable securities - not to hedge - but to meet the needs of specific investor clienteles. Fourth, the new security eliminates a considerable amount of the issuer's risk of holding the underlying security. In order to obtain the necessary data for empirical work, the sample ends in December 2001.

\footnotetext{
12 PHONES are thought to be debt securities because they guarantee holders the return of their investment. DECS are analyzed as a combination of a debt security and a forward contract. Trust structures, in contrast, are thought to be prepaid forward contracts. For a discussion, see Schizer (2000a).

13 The technical issue is whether the debt has been "incurred to purchase or carry" a straddle position (see section $263(\mathrm{~g})$ ). A straddle is itself defined as two offsetting positions in personal property (see section 1092).

${ }^{14}$ See Prop. Treas. Reg. $§ 1.263(\mathrm{~g})-3(\mathrm{c})$.
} 
To construct our sample, we start with a list of transactions from the Global Issues database of the Securities Data Corporation (SDC) in which the security is exchangeable into the common stock of a company other than the issuer. From this list, we search Lexis/Nexis and Dow Jones News Retrieval for news accounts describing the transactions and EdgarPlus for prospectuses, eliminating transactions that do not meet the criteria listed above. Our search through the news media also locates several transactions not identified through SDC.

Overall, the sample includes 61 transactions with gross proceeds of $\$ 24.4$ billion. Table 2 provides the breakdown of our sample over time, indicating whether the issuer is a publicly-traded corporation or a private trust. The first transaction is from 1993. Volume of transactions grew through 1999 but fell in the last two years of the sample. Of the 61 transactions, public corporations issued 37 of the securities and trusts issued the remaining 24 , typically on behalf of high-net-worth individuals. ${ }^{15}$ Thirteen of the transactions are PHONES-type securities, and the others are DECS. For PHONES, interest rates range from 1.00 percent to 3.75 percent, while six of the eleven transactions have interest rates of 2.00 percent. ${ }^{16}$ For DECS, coupon rates are higher. All but three have coupon rates of at least 5.00 percent, and the highest is 10.00 percent.

Table 3 provides basic summary statistics on the transactions. The mean gross proceeds are $\$ 384$ million, ranging from $\$ 12.5$ million to $\$ 1.51$ billion. The securities issued by public firms tend to yield higher gross proceeds. For the public issuers, on average, the value of the exchangeable securities is 10.57 percent of the value of the issuer's equity (measured on the date when the security is issued); however, in the median transaction, the value of the exchangeable securities is only 4.33 percent of the value of the issuer's equity, which suggests that the portfolio positions being hedged are relatively modest compared to the overall value of the issuer's equity. ${ }^{17}$ The average proceeds of the hedging transaction represent 7.85 percent of the overall float of the

\footnotetext{
15 In the "trust" category, we include four transactions in which investment banks issued securities but entered into offsetting private transactions with individuals or mutual insurance companies, thus enabling the latter, in effect, to hedge "through" the investment bank.

${ }^{16}$ These interest rates refer to the coupon rate for the majority of the life of the security. Some PHONES instruments have higher interest rates during the first few years after issuance.

${ }^{17}$ We cannot compute this statistic for the private issuers because the analogous statistic would require information about the overall wealth of the private individuals who are hedging through the trust.
} 
underlying stock, suggesting that these transactions represent substantial blocks of stock in the underlying firms.

To analyze costs associated with exchangeable securities, we need data on various aspects of these securities, including the announcement date. We also need security returns data on the issuer's stock, the underlying stock, and the new security. The SDC database includes information on the exchangeable security's size, maturity, coupon rates, and underwriting costs. If this information is not available from SDC, we use press releases and prospectuses. We calculate the market value of the issuer's equity and the underlying stock using the University of Chicago's Center for Research on Security Prices (CRSP) database. We also use the CRSP data on stock returns and trading volume for the publicly-traded issuer and the underlying stocks.

We collect filing dates from the SDC database or from prospectuses. For announcement dates, we use the earliest mention in the financial press of the exchangeable securities offering (i.e., even if specific terms have not yet been released). If we cannot find information in the financial press or press releases before the filing date for the security, we assign the filing date as the announcement date. An issue about this methodology is that, even if the financial press does not report the announcement, news of the offering may still leak out before the filing date. To correct for this issue, we check our results, as discussed below, by running additional regressions without the transactions that have no separate announcement date.

We also collect data on the price for the new security when it starts trading. We collect these prices from the NYSE's Trading and Quotation (TAQ) database, the Bloomberg database, or the security price listings in the Wall Street Journal, depending on data availability. For the statistical work that uses the prices on the new securities, we use only securities for which trading begins within two trading days of the filing date for the security. Lastly, we collect short interest data on the underlying stocks from the Bloomberg database and data from the NASDAQ.

Theoretically, in order to offer a comprehensive account of the frictions associated with exchangeable securities, we would also need, first, complete data about the frictions associated with alternatives and, second, comprehensive data about the tax benefit from hedging. Thus, two limitations in our data should be reiterated. First, data obviously are not available on the closest 
substitute for exchangeable securities - over-the-counter derivatives transactions - because, by their very nature, these transactions are private. Similarly, data on block sales and serial sales are not easily obtained. Second, the tax basis and tax rates of individual taxpayers are not publicly available, and firms typically do not report this information either. As we discussed in Part I.C.3, we expect that the issuers typically have large unrealized capital gains.

\section{III.Potential Frictions}

Part I outlines four alternatives for taxpayers who want to dispose of a large block of appreciated stock: a block sale; a serial sale; an exchangeable security; and an over-the-counter derivative. Part II describes the data we have collected about the exchangeable security alternative. This Part identifies and measures key frictions that burden exchangeable securities, and compares them with existing evidence on frictions associated with the three alternatives. In particular, this Part reports our empirical findings about four frictions, and mentions three others frictions that are not explored empirically in this article.

\section{III.A. Fees}

Taxpayers must pay underwriting fees to investment banks and legal fees to law firms in issuing exchangeable securities. In trust deals, moreover, they must pay legal fees to create the trust and annual fees to trustees in order to maintain these trusts. Yet comparable costs also arise when taxpayers engage in over-the-counter derivative transactions, and also in block sales. The only cheap transaction, in this regard, is the serial sale.

The last panel of Table 3 compares underwriting fees with gross proceeds. With a few exceptions, the standard fee is three percent of proceeds. The exceptions are concentrated in the sample of public issuers, presumably because these deals are larger on average, and also because public firms (unlike special-purpose trusts) have continuing relationships with underwriters and can exact better terms. This measure of direct transaction costs does not include some of the fixed costs of the deals, such as the advice of tax counsel and, in the case of "trust" deals, the legal fees associated with creating and maintaining the trust. 
While the underwriting fees appear to be a standard percentage of gross proceeds, it is unlikely that underwriting has constant marginal costs. Instead, one would expect that underwriting has both fixed and variable costs, which would lead to a minimum deal size for which the standard percentage contract is profitable. Of the 61 transactions in our sample, only two have gross proceeds of $\$ 50$ million or less, three transactions have gross proceeds between $\$ 50$ million and $\$ 75$ million, and four have gross proceeds between $\$ 75$ million and $\$ 100$ million. We do not have data on underwriting fees for three of the smallest four transactions; for the transaction with gross proceeds of $\$ 50$ million, however, the underwriting fee is 3.5 percent of gross proceeds. The transactions between $\$ 75$ million and \$100 million have the standard three percent underwriting cost. We interpret these data as consistent with a minimum transaction size.

In contrast, Mikkelson and Partch (1985) report substantially higher underwriting fees for secondary offerings. For registered offerings, they report a mean underwriting fee of 6.7 percent of gross proceeds; for non-registered offerings, they report mean fees of 5.0 percent of gross proceeds. On the other hand, the fee would be much lower in a serial sale, in which the taxpayer pays a commission to a broker just as a retail investor would.

\section{III.B. Announcement Effects and Declines in Price of Underlying Stock}

Another cost of hedging with exchangeable securities is that, by definition, the transaction cannot be done in secret. In order to attract buyers, the taxpayer has to announce the transaction before it happens. ${ }^{18}$ The announcement may raise concerns in the market about asymmetric information and corporate governance. For instance, the underlying stock price will decline if the market suspects the taxpayer is selling based on private (negative) information, or if the market believes the taxpayer has been serving a useful monitoring rule that now will end. Because these price declines occur before the taxpayer has implemented the hedge, the taxpayer's profit on the hedged asset is eroded.

\footnotetext{
${ }^{18}$ While the point is obvious with an offering to the public markets, the same is true of a private placement because potential buyers - generally, sophisticated institutions - learn of the taxpayer's interest in cashing out. A difference, though, is that in a private placement the taxpayer can offer less detailed disclosure, and is less likely to be sued under the securities laws. These two costs - preparing disclosure and incurring potential liability - are additional frictions burdening exchangeable securities. The magnitude of these costs is not measured here.
} 
In contrast, other alternatives generally can be implemented more discretely, so the market generally does not know of the disposition until after it has occurred. Obviously, if the sale must be registered (e.g., a secondary offering), it is no more discrete than an exchangeable offering, but registration generally is unnecessary for firms that have held their stock for at least one year. ${ }^{19}$ Even if this holding period has been satisfied, officers, directors, and large shareholders are obligated to disclose transactions in the firm's stock, but this disclosure can come after the transaction has been executed. ${ }^{20}$ Thus, disclosure about a block sale or an over-the-counter hedge is late enough to have no effect on the taxpayer's return. With a serial sale, disclosures about early sales sometimes may have to be made before later sales have taken place; the information effects of such disclosures could reduce the value of the remaining position. While this is a disadvantage of serial sales, the effect should be muted by the fact that disclosure of one sale does not necessarily tell the market that another sale is coming. Disclosure aside, each of these alternatives involves an investment bank, whether as broker or as hedging counterparty, and theoretically the bank could use its advance knowledge of the hedge to bet against the stock, thereby driving down the price. Yet the

\footnotetext{
${ }^{19}$ The origin of this requirement is Section 5 of the Securities Act, which requires the "issuer" and the "underwriter" to supply a prospectus upon selling stock. While this requirement obviously does not apply to an investor that has purchased stock in the public markets, it could apply to an investor that has received stock in a private placement and immediately resells it, since the investor might be viewed as an "underwriter." One way to avoid this problem is to sell such securities in another private placement (i.e., to another qualified buyer under Rule 144A), but the sale price may have to be discounted, since resale of such securities is restricted. Alternatively, the investor can sell the securities in the public markets under Rule 144, but, for the rule to be available, the stock must be held for a year before the sale (and, in some cases, the investor can apply its predecessor's holding period toward this requirement). In addition, the investor must satisfy certain volume and manner of sale limitations, and must file Form 144 no later than the date of the sale. In some cases, advisors believe that investors can hedge on the over-the-counter market even before they can sell (i.e., before the Rule 144 holding period requirement has been satisfied). For a discussion, see Schizer (2001).

${ }^{20}$ An "affiliate," including an officer, director, or certain shareholders that own more than ten percent of a firm, must comply with Rule 144 in selling securities in the public markets (i.e., even if they did not acquire the stock in a private placement). Thus, they must file Form 144 no later than the date of the sale, and they also must comply with volume and manner of sale requirements (but not with the Rule 144 holding period, unless the stock was acquired in a private placement).

Other disclosure requirements can apply to investors with smaller positions that are not officers or directors. The taxpayer that owns five percent of a publicly traded firm is required, under SEC Rule 13D, to report any sales within 90 days after the transaction. Likewise, a taxpayer with a smaller position that is making periodic disclosure (e.g., in a form 10-k) may have to disclose the transaction if it is material, but, again, this disclosure comes after the disposition has been completed.
} 
investment bank has a reputational incentive to be discrete and, in some cases, the risk of insider trading or other securities law liability is a further deterrent. ${ }^{21}$

Thus, there is likely to be greater market scrutiny of an exchangeable offering than of alternatives. To estimate the magnitude of these announcement effects, we use the event study methodology. We regress the total daily return on the underlying stock on the return for the valueweighted market index and a set of dummy variables. We include dummy variables for each day in two eleven-day event windows, one centered on the announcement date, and the other centered on the pricing date.

We define the announcement date as the earliest of either (1) a news account of plans to issue the exchangeable securities security or (2) the pricing date, which is the date on which the securities are priced (typically the day before they are issued). For 19 of the 61 transactions, the announcement date is within two trading days of the pricing date, which implies that it may be difficult to separate the effects associated with the announcement of a security and the execution of the security issuance. By including both event windows in the same regression, the estimates reflect the effects of the announcement holding the effects of execution constant (and vice versa). As an alternative methodology for estimating the announcement effects, we focus on the 42 securities for which the announcement precedes the execution by more than two days and estimate the model with just the announcement effect window.

The market model allows each underlying's stock to have a different sensitivity (i.e., market beta) to returns on the market portfolio. To estimate the model, we include available daily stock returns over the period starting 500 trading days before the filing date for the exchangeable security and ending with the maturity date of the exchangeable security or the end of 2001 if the security matures after December 2001.

Panel A of Table 4 provides the average abnormal returns for the sample of underlying securities. The first column provides estimates of the eleven-trading-day window centered on the

\footnotetext{
${ }^{21}$ Where the bank is the hedging counterparty, moreover, the investment bank will not want news of the disposition to disseminate until after the bank has hedged its own exposure on the derivative it has sold to the client (and, in the usual case, the investment bank hedges by shorting the stock). This incentive is diminished in cases where the investment bank passes this risk on to the client (i.e., by tying the price on the taxpayer's derivative to the price attained by the investment bank on its short sales).
} 
announcement date. On the announcement date, the underlying securities have an average excess return of -0.51 percent, but this estimated effect is only statistically different from zero (using a two-tailed test) at the 74 percent confidence level. Considering longer event periods suggests a larger negative effect but without much statistical precision. For example, over the five-day window centered on the announcement date, the cumulative average abnormal return is -1.92 percent but the p-value for the F-test of whether this set of coefficients differs from zero is 0.32 ; for the announcement day and the following two days, the cumulative average abnormal return is -1.62 percent with a p-value of 0.14 .

Panel B of Table 4 reports the median abnormal return on each of the days in the event-window and the percent of transactions with a positive abnormal return on each day. Consistent with the average abnormal returns from the regression, the median abnormal returns and percent positive suggest that the announcement of the issuance of exchangeable securities has a negative effect on the value of the underlying stock but the statistical significance of this result is marginal at best.

As another way to examine whether our results are tainted by transactions for which the announcement date is potentially ill-defined, we estimate the announcement window for the 42 transactions in which the announcement date precedes the pricing date by more than two trading days. The estimated effects (not reported in a table) are larger in magnitude but of marginal statistical significance. The announcement day abnormal return is -0.31 percent (t-statistic $=$ $-0.68)$ but the day after the announcement has an abnormal return of -0.85 percent (t-statistic $=$ -2.12). The five-day event window has an estimated abnormal return of -2.47 percent ( $\mathrm{p}$-value for the F-test $=0.14$ ) and the three-day window starting with the announcement date has an estimated abnormal return of -1.82 percent $(p$-value $=0.061)$.

Since there are variations within our sample, one could imagine that the announcement effects on the underlying stocks depend on the type of security, although, given the small size of our sample, we approach sample splits with caution. Most importantly, we test whether trust deals generate larger announcement effects. The theory is that trust deals may convey news about how an individual insider feels about the prospects of the underlying firm. In contrast, many of the public issuers have no direct link to the underlying firm. Consistent with this hypothesis, the negative 
announcement day effects are concentrated in the sample of trust-based deals. ${ }^{22}$ For example, for the two-day window starting one day before the announcement day, the abnormal return on transactions with corporate issuers is 0.26 percent but the abnormal return for trust transactions is -2.45 percent and this difference is statistically significant at the 95 percent confidence level. ${ }^{23}$

These announcement effects are smaller than those found in secondary offerings. Mikkelson and Partch (1985) estimate a -2.87 percent two-day abnormal return for the announcement of a registered secondary offerings using data from $1972-1981 ;^{24}$ for non-registered offerings the timing of the announcement effect is slightly later (i.e., it occurs mainly on the day after what they define as the announcement day) and the abnormal return is only -1.96 percent. Consistent with this result, Hudson, Jensen, and Pugh (1993) find a -2.65 percent two-day announcement effect for completed secondary offerings using data from 1974 - 1989. One reason that secondary offerings may have a more negative announcement effect than the exchangeable securities is that the issuers in our sample retain some upside potential, although the fact that this exposure is retained in part for tax purposes should render it less reassuring to the market.

In examining exchangeable debt from the 1970s and 1980s, Ghosh, Varma, and Woolridge (1990) also find that the announcement impacts the underlying share price, causing two-day abnormal returns of -1.11 percent. Based on anecdotal evidence, Ghosh, Varma, and Woolridge consider it unlikely that issuers have substantial evidence of the future prospects of the underlying stock. Instead, they posit that the dilution of ownership has a negative effect on monitoring and future share value. ${ }^{25}$

\footnotetext{
${ }^{22}$ An alternative possibility is that the timing of the effects is different. The negative effects on the underlying stock in the trust-based deals, relative to the corporate issuers, are concentrated on the day before and the day of the announcement. In contrast, for the two days following the announcement day, the underlying stocks in deals with corporate issuers fall by 1.53 percent but those associated with trust-based deals fall by only 0.34 percent; this difference, however, is imprecisely measured.

${ }^{23}$ To test another variation in our sample, we compare PHONES and DECS. We find that the estimates are too noisy to detect any difference.

${ }^{24}$ Consistent with the possibility that the negative effect depends on the closeness of the selling shareholder to the governance of the underlying firm, Mikkelson and Partch (1985) find that the negative effect is larger when the registration is on behalf of a corporate manager or director.

${ }^{25}$ A potential difference in the signaling effects associated with those transactions is that the issuer continued to bear risk of loss in the underlying stock, unlike the mandatory exchangeables in our sample.
} 
Overall, despite the statistical imprecision of the estimated announcement effects in our sample, the magnitude of these effects seems reasonable compared to studies of similar transactions. We conclude that announcement effects are one cost of hedging with public securities. Since secondary offerings yield larger effects, exchangeable securities are less costly in this regard than one-time sales of stock. Moreover, this cost should be more important for issuers that are perceived to have inside information.

\section{III.C. Execution of the Transaction and Price Pressure}

The underlying stock price can be affected not only by the announcement, but also by the execution, of exchangeable offerings. In an execution effect, the price decline is not driven by information (e.g., the negative signal when an insider sells), but by liquidity. ${ }^{26}$ In a fragmented securities market, a sudden surge of sale orders can trigger a temporary dip in price. ${ }^{27}$ Since the exchangeable securities are close substitutes for the underlying stock, the offering may function like a sale of a large block of stock. Typically, the entire offering is issued on the same day. ${ }^{28}$ Thus, in anticipation of a price decline, the underwriter may discount the offering price, reducing the taxpayer's proceeds (and thus the profit from the appreciated asset).

Notably, this cost also arises in a block sale. In contrast, a serial sale is less likely to trigger this effect. By selling in drips and drabs, the taxpayer hopes to avoid flooding the market. ${ }^{29}$ An overthe-counter derivative can also be constructed to avoid this liquidity effect. The hedge can take effect over a few days - with a portion of the position hedged each day - so the investment bank's short sales are not concentrated enough to cause price pressure.

\footnotetext{
${ }^{26}$ There is one exception: Execution of the offering can convey information when the market is uncertain whether the announced transaction will be completed.

${ }^{27}$ These effects are discussed in the literature on the price elasticity of stocks (or, "does the demand curve for stock slope down?"). See, among others, Hodrick (1999), Holthausen et. al. (1990), and Shleifer (1986).

${ }^{28}$ In fact, it is difficult to issue a security to public markets over the course of several days. For one thing, the disclosure must be updated for each mini-offering (although, to an extent, this problem can be ameliorated with a so-called shelf registration). Also, in order for the various mini-offerings to be fungible, they have to have the same economic terms. Yet this goal is hard to achieve if the securities are issued on different days, assuming (as is customary) that the exchangeable security's issue price is the same as the underlying stock price when issued.

${ }^{29}$ If the sale must comply with Rule 144 (e.g., because the seller is an affiliate or because the stock was originally received in a private placement), the seller must comply with volume and manner of sale limitations. Given the limits on how the selling broker can "shop" a customer's offer in these circumstances, the seller may not get the best execution.
} 
Thus, price pressure is more important for exchangeable securities than for key alternatives. To estimate the magnitude of this friction, we examine the price of the underlying stock around the issue date; the estimated average abnormal returns from the eleven-day window around the issue date are in the second column of Panel A of Table 4. Again, we estimate the effects of the announcement date and the filing date in the same model so that we do not confound information effects from announcement with execution effects. On the day before the filing date, the abnormal return for underlying stock is -0.95 percent, and is statistically significant at the 95 percent confidence level. On the filing date, the abnormal return is -2.38 percent and statistically different from zero at the 99 percent confidence level. For the two day period, the abnormal return is -3.33 percent, suggesting that the underlying stock faces price pressure when the exchangeable security is issued. ${ }^{30}$ Panel B of Table 4 examines the median abnormal returns and the percent of abnormal returns that are positive. These data are consistent with our inferences about average abnormal returns.

Price pressure sometimes is a transitory phenomenon caused by placing a large order over a short period of time. If the price pressure is a transitory effect, then the price of the underlying stock should rebound shortly after the negative effect of the transaction. While the abnormal return on the underlying stock for the first five days after the filing day is a combined 1.31 percent, this estimated effect is only statistically different from zero at the 80 percent confidence level. In any event, a rebound does not wholly compensate the issuer for the price pressure because the decline occurs before the issuer hedges, while the rebound occurs after the hedge is in place.

The issuer's participation in the rebound depends on features of the hedging security. After issuing a DECS, for example, the issuer still holds the stock but also is, effectively, short an out-ofthe-money call option on the stock and long at-the-money put option on the stock. While the issuer nominally retains all appreciation just above the initial stock price (i.e., up until the exercise price on the call option), the issuer, in fact, does not keep this entire value: Unfortunately for the issuer, this appreciation reduces the value of the put option purchased by the issuer and, correspondingly,

\footnotetext{
${ }^{30}$ These abnormal returns do not vary systematically across trust-based and corporate issuer transactions or across PHONES and DECS. In addition, we obtain similar results if we exclude observations for which the announcement date is within two days of the pricing date.
} 
increases the value of the call option sold by the issuer, thereby increasing the issuer's liability on the DECS. ${ }^{31}$

Finally, a caveat is in order. While the underlying stock price clearly declines when the exchangeable security is issued, and we believe at least some of this decline is attributable to price pressure that arises from market microstructure, as discussed here, it is possible that some (or, conceivably, all) of this price decline is attributable to a different friction. The most likely candidate, in our view, is the need to offer public investors generous pricing. We now turn to that cost.

\section{III.D. Generous Pricing for Public Investors on Hedging Security}

In theory, it is difficult to say whether issuers have to offer generous pricing to investors in order to sell exchangeable securities. On one hand, there are reasons why generous pricing would be necessary, and, on the other hand, reasons why it would not. After outlining the competing considerations, we turn to the empirical evidence.

\section{III.D.1. Why Generous Pricing May be Necessary}

While exchangeable securities are close substitutes for the stock, they are not perfect substitutes. Although typically issued at the same price as the underlying stock, their economic terms are not the same. DECS, for instance, offer a larger periodic payment in return for less opportunity for gain. ${ }^{32}$ The key point is not that the securities are different per se, but that these differences may be unfamiliar. Hence, public investors may demand discounted pricing before

\footnotetext{
${ }^{31}$ For example, when the stock price is $\$ 100$, a 5-year call option with a strike price of $\$ 120$ has a BlackScholes value of $\$ 26.120$, assuming volatility of 0.27 , an interest rate of 5 percent and no dividends. When the stock price rises by a dollar, the Black-Scholes option value increases to $\$ 26.780$. By selling such a call through a DECS, then, the issuer loses $\$ 0.66$ on the DECS as the stock price rises from $\$ 100$ to $\$ 101$. To be precise, though, the issuer sells only a fraction of a call: Since the holder typically gets only 83 percent of the appreciation above $\$ 120$, the issuer only loses $\$ 0.55$ (83 percent of $\$ 0.66$ ) by being short the call option. As noted, the issuer also loses on the at-the-money put option embedded in the DECS. Worth $\$ 11.976$ when the stock price is $\$ 100$, the put value declines by $\$ 0.238$ to $\$ 11.738$ when the stock price is $\$ 101$. Overall, then, the issuer gains $\$ 1$ from the price increase by owning the stock but losses $\$ 0.788$ from the options embedded in the DECS, for an overall gain of $\$ 0.212$. Thus, the issuer participates fully in the underlying stock returns before issuance (the decline) but participates only partially in these returns after issuance (the rebound). On the assumed facts, the issuer participates in roughly 20 percent of subsequent appreciation.

${ }^{32}$ In a case study, Petersen (2001) values a DECS issued by Solomon Brothers based on Cincinnati Bell stock. In that case, the critical issue is whether dividends will remain at their historical level, or will be increased to preserve the historic yield.
} 
accepting such complexity. ${ }^{33}$ In addition, the exchangeable security is less liquid than the underlying stock because it has a smaller float. If investors value liquidity, they will prefer the stock unless the exchangeable security offers generous terms. ${ }^{34}$

If generous pricing is needed, it represents a friction that is unique to exchangeable securities. Obviously, such a discount is not needed if the issuer merely sells the stock, whether in a serial sale or in a block sale. A discount also should not be necessary in an over-the-counter derivative transaction, since a securities dealer will not be daunted by complexity or illiquidity, given the dealer's expertise and its ability to hedge the derivative through short sales in the public markets. (The assumption here is that dealers are subject to enough competitive pressure so they cannot charge for factors that do not increase their costs.)

Assuming that exchangeable securities must be issued at a discount - and reasons why a discount may be unnecessary will be outlined shortly - what effect on the market will such a discount have? Discounted pricing should have at least three effects, and a fourth is also possible. First, volume in the underlying stock should increase when the exchangeable security is issued. Once this security becomes available, some investors who already own the stock will sell it, replacing it with exchangeable securities. This clientele will be relatively indifferent to the latter security's complexity and illiquidity because these investors (e.g., university endowments) are sophisticated and plan to hold the security for the long term. Second, the short interest in the underlying stock should rise when the exchangeable security is issued. Once this security becomes available, arbitrageurs, who may not already own the underlying stock, are likely to sell it short and buy the exchangeable security as a way to capitalize on the generous pricing. Third, the price of the underlying stock should decline when the exchangeable security is issued. The sales described above - and, more generally, the fact that a more generous alternative has become available - could suggest declining demand for the underlying stock.

\footnotetext{
33 Cf. Kang and Lee (1996) (finding that convertible bonds have an excess return, relative to an index of convertible bonds, of 1.11 percent; and arguing that this underpricing of convertibles on the first day of reported trading is a discount, which is needed because of uncertainty about the convertible's true value).

${ }^{34}$ For a general discussion of how illiquidity can affect stock returns and raise the required rate of return on a security, see Brennan and Subrahmanym (1996).
} 
Finally, the price of the exchangeable security may rise relative to the price of the underlying stock, although this will not necessarily occur. The key question is which investor benefits from the generous pricing - or, to be more precise, how long it will take for this generous pricing to be corrected. If initial investors capture this benefit, then investing in the exchangeable security will generate positive excess returns shortly after trading begins. For generous pricing to be a shortterm phenomenon, a subsequent purchaser must not also demand generous pricing. Yet in the case of liquidity and complexity, subsequent purchasers presumably would also demand generous pricing. If so, the generous pricing would compensate long-term holders over the life of the contract (e.g., through above-market periodic payments).

\section{III.D.2. Why Generous Pricing May Not Be Necessary}

It is also possible, however, that there is no need to offer generous pricing. For some clienteles, exchangeable securities may be more appealing than the underlying stock. Under state law, pension funds and insurance companies are required to hold a minimum percentage of assets in debt securities. Yet managers of these portfolios may prefer the greater expected returns associated with equity. Exchangeable securities have the advantage of offering equity returns, while being treated by these (unsophisticated) state law regimes as debt securities. ${ }^{35}$ In addition, if the underlying stock is a growth stock that pays no dividend, as often is the case, some investors may prefer to give up a portion of potential appreciation in return for a periodic payment. Indeed, investment banks sometimes issue exchangeable securities - not to hedge appreciated stock holdings - but to satisfy market demand. ${ }^{36}$ Hedge funds also value the differences between exchangeable securities and the underlying stock since they can exploit these differences in various trading strategies that are discussed below.

Since theory does not tell us whether generous pricing is needed, the key question is what data can tell us the answer. Short-term generous pricing can be ruled out if the price of the exchangeable does not rise relative to the price of the underlying stock. On the other hand, long-term mispricing

\footnotetext{
35 See Schizer (2000c). Foreign investors might also favor these securities as an alternative to equity, which is subject to a withholding tax on dividends. Yet there is some risk that these exchangeable securities might also be subject to withholding tax, at least in some circumstances. In any event, anecdotal evidence suggests that these securities are sold primarily to U.S. investors.

${ }^{36}$ For instance, Morgan Stanley has issued a number of such deals off its "shelf" registration statement.
} 
is harder to pin down. In this regard, a spike in the underlying stock's volume and short interest are ambiguous evidence. The reason is that at least two trading strategies, commonly used by hedge funds, involve holding an exchangeable security and shorting the underlying stock, but do not necessarily depend on generous pricing.

In the first strategy, hedge funds place bets on the volatility (as opposed to the direction) of the underlying stock price. In buying a DECS, the fund in effect buys an out-of-the-money call option (giving it opportunity for gain above 120 percent of the then-current market price) and sells an atthe-money put option (giving it risk of loss below the then-current market price). An increase in the underlying stock's volatility increases the value of both these options (one of which is an asset to the fund, and the other of which is a liability). Typically there will be more appreciation in the call (the asset), causing a net increase in the value of the DECS. This is true even if the stock price does not change or, for that matter, if the fund has hedged stock price changes by engaging in short sales, as is usually the case. Thus, "CBA [convertible bond arbitrage] managers are generally long volatility." ${ }^{37}$ This strategy might be premised on generous pricing, for instance, if issuers discount the premium they charge for the option that is embedded in the exchangeable securities, a step the

\footnotetext{
${ }^{37}$ There is another way to extract volatility-related returns for convertible bonds that are principal-protected, but the strategy is harder to implement for exchangeable securities, which do not offer meaningful principal protection. The key lies in the "delta" of the security - that is, the amount the security's price changes when the stock price changes by one dollar (see Burnaby-Atkins (2002).

For principal-protected bonds, when the stock price is very low, so that a principal-protected bond is unlikely to be converted, changes in the stock price will cause only modest changes in the bond's value. On the other hand, when the stock price is very high, so that the bond is nearly certain to be converted, a dollar change in the stock price will cause essentially a dollar change in the bond's value. Thus, the delta of these bonds increases as the stock price increases. As a result, when a hedge fund dynamically hedges a principalprotected bond, it will make money from imperfections in the hedge both when the stock price rises, and when it falls. Consider, for example, a bond that is convertible into one share and offers principal protection of $\$ 100$ (so the embedded call option has an exercise price of $\$ 100$ ). Assuming the bond's delta is .5 when the stock price is $\$ 100$, the fund will hedge at this stock price by shorting one half of a share for each bond. If the stock price rises to $\$ 105$, the short sale will decline by $\$ 2.50$, but the convertible bond will increase by more than $\$ 2.50$ (because, by the time the stock price rises to $\$ 104$, the bond's delta is greater than .5). Correspondingly, if the stock price falls to $\$ 95$, the short sale will appreciate by $\$ 2.50$ but the bond will appreciate by less than $\$ 2.50$ (because, by the time the stock price falls to $\$ 96$, the bond's delta is less than $.5)$.

The key to this strategy is that delta increases with the stock price. Yet while this condition holds for principal-protected securities, it does not hold for the exchangeable securities in our study, which do not offer meaningful principal protection. On these securities, delta is high when the stock price is either very low or very high, but is lower when the stock price is between $100 \%$ and $120 \%$ of the security's issue price (because the issuer retains opportunity for gain in this trading range). The strategy "works" - in the sense that it yields profits regardless of the market's direction - only in trading ranges in which delta is increasing.
} 
issuer might take to compensate holders for the relative complexity and illiquidity of these securities. But it is also possible that the securities are fairly priced, given current market conditions, and fund managers are betting that market conditions will change (i.e., so volatility will increase). In the latter circumstance, exchangeable securities offer a relatively unique and liquid means of placing this bet, given that their term is three to five years; in contrast, most publiclytraded options have a term of less than one year. ${ }^{38}$

In addition to bets on volatility, there is a second strategy in which hedge funds use short sales without necessarily relying on generous pricing: they "strip the coupon" off a convertible security in effect, using a cheap source of funds to finance a low-risk return. For instance, assume the exchangeable security costs $\$ 100$, as does the underlying stock. Assume also that the correlation in their trading prices (the so-called "delta") is not perfect (i.e., because the exchangeable security does not pay holders the first 20 percent of opportunity for gain). Thus, when the security is first issued (for \$100), a one dollar change in the value of the underlying stock causes an 80 cent change in the value of the exchangeable security. Given this delta of .80, the hedge fund will hedge the security by shorting $\$ 80$ worth of stock (i.e., .80 of a share). While the fund does not have direct access to this $\$ 80$ of short sale proceeds, the fund, as a valued high-volume customer of the broker that has implemented the short sale, will earn interest on this $\$ 80$ (a "short sale rebate"). ${ }^{39}$ In fact, the short sale rebate is likely to be high - only 50 basis points less than the hedge fund's borrowing cost. On top of this negative spread, the fund will have to pay another 50 basis points to borrow the stock needed for the short sale. Thus, assuming (1) the fund has borrowed $\$ 80$ toward purchasing the convertible bond and (2) the stock does not pay a dividend, this trading strategy has an annual carrying cost of only 80 cents. In addition, the fund must put up twenty dollars of its own capital to buy the exchangeable security. At the same time, the fund is earning a coupon on the exchangeable security, which might be four dollars per year. Net of expenses, the fund is earning $\$ 3.20$ on $\$ 20$ of capital, or $16 \%$ per year. Since the net position is effectively a fixed income investment, the fund bears risk that interest rates or the issuer's credit will change.

\footnotetext{
${ }^{38}$ There is a developing market in LEAPS, which have longer terms, but this market was relatively thin during the period for which we have data (see Schizer (2001)).

${ }^{39}$ This rebate is a crucial element of this trading strategy, and it would not be offered to less favored customers, such as most individual investors.
} 
Some of the profit here may arise from overly generous pricing on the exchangeable security's coupon. Yet some also arises from the cheap financing the fund is able to secure. By shorting the stock, the hedge fund in effect is able to borrow short sale proceeds for one percent per year. The trick - since the fund does not want to take market risk on this short sale - is to find an offsetting position that yields more than one percent per year. Obviously, an exchangeable security fits this bill, causing hedge funds to demand these securities. Coupon stripping is an especially attractive strategy with exchangeable securities because they do not offer principal protection, and thus make relatively high periodic payments.

To sum up, there are reasons why generous pricing may not be needed for exchangeable securities, and evidence of a rise in the underlying stock's volume and short interest could be consistent with this view.

\section{III.D.3. Empirical Evidence}

To test for abnormal trading volume, we regress the logarithm of the daily trading volume on the logarithm of shares outstanding for the underlying stock (taken from the CRSP data base), a set of transaction-specific constants, a set of transaction-specific sensitivities to overall market volume (as measured by the logarithm of daily volume on the New York Stock Exchange), and a set of dummy variables for the days in eleven-day windows centered on both the announcement and filing dates for the hedging security. The logarithm of shares outstanding captures the idea that equities with more shares outstanding will have higher volume. The deal-specific dummy variables allow each underlying stock to have its own average volume. The dummy variables for the windows around announcement and filing capture abnormal daily volume around the important dates for the hedging security.

Table 5 reports the results. Specifically, the second column reports the abnormal trading volume around the filing date. ${ }^{40}$ On the filing date, volume in the underlying stock is almost double the normal volume and, on the day after the filing date, volume is 140 percent greater than normal.

\footnotetext{
40 The first column, which is less relevant to our hypothesis, shows trading volume both before and after the announcement day. This volume is roughly 25 percent below the average trading volume for the security. These daily differences are often statistically different from zero at the 95 percent confidence level. These results suggest that trading volume in the underlying is slightly depressed (relative to earlier and later trading volume) around the announcement date. While the days surrounding the announcement have unusually low trading volume, the trading volume on the announcement day is very close to normal.
} 
This abnormally high volume starts just before the filing date, persists on the first day after the filing date, and decays thereafter. The two days preceding the filing date have excess volume of 38 percent and 36 percent, respectively. Volume is more than 60 percent above normal on the second and third days after the filing date, and is 45 percent above normal on the fourth and fifth trading days after the filing date. As noted above, though, an increase in volume is ambiguous evidence, which is consistent with both generous pricing-related and nongenerous pricing-related trading.

As a more specific test for convertible arbitrage activity, we examine the short interest on the underlying stock, both when the exchangeable security is issued and when it matures. ${ }^{41}$ Short interest data are reported on the $15^{\text {th }}$ of each month from brokers. To measure changes in short interest, we compare the observation immediately after the issuance with the observation immediately before the issuance and, to allow more time for hedge funds to act (and to avoid increases in anticipation of issuance), we compare short interest two observations after the issuance date with short interest two observations before the issuance date. As a simple measure of short interest, we measure whether short interest increases or decreases between the two comparison observations.

We can obtain short interest data around the issuance of 45 transactions. Using the observations immediately before and after the issue date, we find that 36 underlying stocks experience an increase in short interest activity and nine experience a decrease. We can reject the hypothesis of random increases and decreases (i.e., the null hypothesis of a 0.50 probability of an increase) at the 99 percent confidence level. When we use the longer horizon, we find that the short interest increases in 39 of the 45 transactions. This change provides compelling evidence that more investors short the stock after the exchangeable security is issued, which is consistent with convertible arbitrageurs shorting the stock.

An alternative explanation for increased short interest around the issue date is that news of the exchangeable security increases the pessimism of other investors, inducing them to short the underlying stock. To eliminate this information-based explanation, we examine the short interest around the maturity date. Since maturity is easy to predict and occurs well after the issue date, it is

\footnotetext{
${ }^{41}$ For more on short interest and arbitrage activity, see Brent et. al. (1990).
} 
unlikely that maturity prompts any information-driven short sales. In contrast, maturity of the security will induce convertible arbitrageurs to unwind their short positions. In other words, even if a surge in short interest upon issuance is not definitive evidence of convertible arbitrage, a reduction in short interest at maturity is very strong evidence of this activity.

The change in short interest at maturity is even more striking than at the issue date. Of the 25 transactions for which we have short interest data at maturity, over the one month horizon 23 underlying stocks have a decrease in short interest. Using the two observation window, the number rises to 24 . In both cases, we can reject the null hypothesis that changes in the level of short sales are random.

To test more directly for short-term generous pricing, we compare the initial returns on the exchangeable securities and underlying stock over the same period. Our methodology follows studies that look at underpricing of initial public offerings of stock. A key difference is that our benchmark is not the overall market, but the underlying security (which, for almost all of the exchangeable securities, has the same initial value as the issue price of the exchangeable security). ${ }^{42}$ While the exchangeable security and underlying stock offer somewhat different payoffs, they should trade in tandem when the underlying stock price fluctuates modestly near the initial offering date. Over time, however, larger discrepancies should arise due to different features of the two securities (e.g., the difference between the coupon and the dividend, the retention of upside potential by the issuer, the impending maturity date, etc.).

For a sample of 42 transactions, we identify trading data within two days of the filing date. We calculate the return on the exchangeable security as the difference between the offering price and the last traded price at the end of the first day of trading, the second trading day, and the third trading day. For these deals, the average returns on the exchangeable security over these three intervals (i.e., the third interval is a three-day return) are $1.21,1.51$, and 1.78 percent, respectively. These returns indicate a positive return to the original owner of the exchangeable security. However, the returns on the underlying stock are also positive over these three intervals with

\footnotetext{
${ }^{42}$ Given the nature of the exchangeable security, one would expect it to have similar exposure to market risk as the underlying stock. Thus, comparing the returns of the exchangeable security and the underlying stock implicitly controls for market risk.
} 
average returns of $0.66,1.27$, and 1.52 percent, respectively. Excess returns on the exchangeable securities over the three intervals $-0.55,0.24$, and 0.26 percent - are not statistically different from zero at conventional confidence levels. Thus, the evidence does not suggest that short-term holders benefit from mispricing.

It is still possible that long-term holders benefit from underpricing, but it is not feasible to test for this effect directly. Over time, it is more difficult to compare returns of the exchangeable security and underlying stock because cash flows differ and non-linearities in the exchangeable security's payoff become more important. ${ }^{43}$ Yet the fact that the underlying stock price declines when the exchangeable is issued, as noted above in Part III.C., is consistent with the idea that certain clienteles, who are relatively tolerant of complexity and illiquidity, are selling their stock in order to buy the exchangeable security. In other words, this substitution effect -- and not the market microstructure explanation offered in Part III.C. - may be responsible for some (or all) of this price decline.

\section{III.E. Other constraints}

Three other frictions, which are not explored empirically here, can burden both an offering of exchangeable securities and an over-the-counter transaction, but not a block or serial sale. In other words, these costs apply only to the tax-deferred alternatives, and burden these more or less equally. First, in order to avoid a current tax, the issuer must remain exposed to (relatively modest) fluctuations in the underlying stock, whether the issuer is hedging with exchangeable securities or over-the-counter derivatives.

Second, corporate taxpayers that engage in complex financial transactions, including exchangeable securities and over-the-counter derivatives, may become subject to special market scrutiny, since investors may become concerned that they do not understand what the firms are doing. While this friction has become more significant in the wake of Enron's failure, it probably was less important during the period that we study.

\footnotetext{
${ }^{43}$ Put another way, assessing long-term mispricing requires estimates of various parameters that inform the value of derivatives embedded in the securities. Uncertainty over these parameters complicates assessing long-term mispricing.
} 
Third, corporate taxpayers can face adverse financial accounting when hedging with an exchangeable security or an over-the-counter derivative. Financial Accounting Standard 133 ("FAS 133"), which became effective on July 1, 2000, requires firms periodically to report on accounting statements the fair market value of certain derivative positions. ${ }^{44}$ Depending upon the rule's precise application, it could introduce undesirable volatility in the earnings of firms that hedge an appreciated stock position - volatility that does not accurately reflect the firm's true economic position. The concern is that the firm would have to report changes in the value of the hedge, but would not also be able to report offsetting changes in the underlying stock being hedged. As an illustration of this accounting mismatch, assume the hedged stock appreciates by 50 percent. This gain is not reflected in earnings (because the stock is not being marked to market, and has not been sold), but the corresponding loss on the derivative would be reflected (because it is being marked to market). The firm would thus appear unprofitable, even though no economic loss has occurred.

To avoid this mismatch, firms will want their transactions to qualify for "hedge" accounting, a special rule within FAS 133 that, in effect, allows both positions - the hedge and the hedged asset to be marked to market. In the example above, losses on the hedging transaction would be offset by gains on the hedged asset, so no accounting loss would be recorded. Yet hedge accounting is not always available. For example, one prerequisite for hedge accounting is a relatively close correlation between the hedge and hedged asset. ${ }^{45}$ For tax reasons, however, the taxpayer will not want the correlation to be too close, or the hedge will trigger a taxable constructive sale (see Schizer (2001)).

\section{III.F. The Advantage of Private Transactions}

Thus far, we have documented costs that arise in exchangeable securities offerings but not in private over-the-counter transactions. Our findings help explain the market's preference for private transactions, a preference that previously has been established only through anecdotal evidence. ${ }^{46}$

\footnotetext{
${ }^{44}$ Accounting for Derivative Instruments and Hedging Activities, Statement of Financial Accounting Standards No. 133 (Financial Accounting Standards Bd. 1998).

${ }^{45}$ See FAS 133.20(b) (requiring, as condition for qualifying as fair value hedge, that "the hedging relationship be expected to be highly effective in achieving offsetting changes in fair value").

${ }^{46}$ Obviously, empirical research on private transactions would allow for a more definitive judgment (e.g., in assessing costs that might arise in private deals but not in public ones), but data limitations are a significant obstacle here. For a detailed anecdotal survey of costs associated with private deals, see Schizer (2001).
} 
While the purpose of this paper is positive, rather than normative, our findings have (modest) implications for reform. For instance, as one of us has written elsewhere, private transactions are vulnerable to government responses that would not reach public exchangeable offerings. ${ }^{47}$ If the government were to target private transactions, would taxpayers respond by merely substituting public transactions? The extra costs of public transactions documented here suggest that, at least in marginal cases, such substitutions would not occur. Yet in other cases, such substitutions might well occur, triggering added social waste as inframarginal taxpayers use more expensive hedges. One reason why such substitutions are likely is suggested by the evidence in the next section: the tax savings from exchangeable offerings can outweigh the costs - a fact that (perhaps not surprisingly) would seem to be true of the deals in our sample.

\section{Taxpayer Stock Price and the Announcement of Exchangeable Offerings}

In this Part, we explore whether the taxpayer's stock price rises when an exchangeable offering is announced. ${ }^{48}$ Such a market vote of confidence would imply that the tax savings or other benefits from these transactions outweighed the costs. A caveat is in order, though. The market is reacting not only to the decision to hedge and raise money, but also to possible uses of the proceeds. In our sample, issuers typically say proceeds will be used for "general corporate purposes," so we are unable to test whether announcement effects are related to the use of proceeds. ${ }^{49}$ The fact that

\footnotetext{
${ }^{47}$ The main vulnerability of private transactions is that dealers ordinarily hedge the derivatives they have sold to clients, typically by engaging in short sales in the public market. (In public exchangeable offerings, in contrast, the counterparty is a public investor - not a dealer - and thus does not necessarily need to hedge.) To implement the requisite short sales, dealers must borrow the underlying stock. In large transactions, dealers usually want to borrow the taxpayer's stock. Yet this step weakens the tax analysis, and the government could easily use regulatory authority to prevent this borrowing of stock (see Schizer (2001)). ${ }^{48}$ Obviously, trust-based transactions cannot be tested in this way because we cannot measure the market value of the taxpayer who is hedging through the trust.

${ }^{49}$ While the most commonly-stated use of proceeds for corporate issuers is "general corporate purposes," press accounts sometimes link the securities issuance to new investment initiatives or the retirement of other debt. In the case of Alliant Energy's PHONES transaction based on McLeodUSA, managers felt that the market did not recognize the value of Alliant's investment; over the thirteen month period before issuing the security, McLeodUSA's stock appreciated by almost 400 percent but Alliant's stock price fell by three percent (see Sherer, 2000). Alliant's position in McLeodUSA was worth \$2.6 billion and accounted for over half of Alliant's market capitalization. The PHONES transaction hedged roughly 15 percent of this position. Thus, in this example, the managers hoped the news would focus on the value they could realize from their portfolio investment in addition to the possible uses of funds. As an aside, while Alliant's managers faulted investors for not appreciating the value of McLeodUSA, the subsequent stock performance suggests Alliant's investors may have been clairvoyant. By the end of 2001, McLeodUSA's stock traded at a price below its value in December of 1998.
} 
proceeds are not typically earmarked, though, suggests that the most salient new information is the combination of the hedge and the financing, rather than the specific use of proceeds.

\section{IV.A. Announcement Effects for Issuers of Exchangeable Securities}

To examine announcement effects on the issuer's stock, we run an event study like the one we ran for the underlying stock. However, we make several changes. First, we focus solely on announcement effects since execution of the offering is unlikely to have a direct effect on the issuer. Second, to capture the possibility that changes in the underlying stock have a direct valuation effect on the issuer, we include the daily abnormal returns for the underlying stock. We measure these abnormal returns as the residuals from a market model for each underlying stock. We allow the responsiveness of the issuer's stock to the underlying stock to differ after the issuance of the hedging security. One would expect that the issuer's stock would be less sensitive to the underlying stock after issuing the exchangeable security. We also include a separate dummy variable that captures returns after the issuance of the exchangeable security.

The first column of Table 6 presents the average abnormal return for each of the 11 days in the announcement period. On the announcement day, the issuer has an abnormal return of 0.88 percent, which is statistically different from zero at the 95 percent confidence level. Thus, the market responds positively when exchangeable offerings are announced. As expected, the issuer's stock is positively related to idiosyncratic movements in the underlying stock. Before the issuance, a one percent abnormal return for the underlying stock would be associated with a 0.061 percent additional return for the issuer. However, after hedging, this sensitivity is reduced by about onethird (i.e., the coefficient on the interaction term with the dummy variable for days after the security is issued is -0.020) and this reduction is statistically different from zero at the 95 percent confidence level. ${ }^{50}$

\section{IV.B. Comparison with Announcement Effects of Similar Transactions}

While Table 6 documents a modest positive market response to the issuance of an exchangeable offering, a natural question is how this reaction compares to similar financings. The most well-

\footnotetext{
${ }^{50}$ Three factors explain why the issuer's exposure to risk in the underlying remains positive after the security is issued. First, some of the issuers are in the same industry as the underlying so the coefficient also captures industry-specific influences. Second, the securities do not offer a perfect hedge. Third, some issuers only hedge part of their position in the underlying.
} 
known announcement effect for financings is the negative effect of a seasoned equity offering, a result that is consistent with managers issuing shares when the firm's equity is overvalued. This signaling story is analogous to our finding that an exchangeable offering contains a negative signal about the underlying stock.

For announcement effects on the issuer's stock, in contrast, three other transactions may provide a closer analogy: (1) classic (principal protected) exchangeable debt; (2) asset securitization; and (3) an asset sale. ${ }^{51}$ For classic exchangeable debt, Ghosh, Varma and Woolridge (1990) find a trivial (0.04 percent) abnormal return for the announcement window and Barber (1993) finds a similar result.

For asset securitizations (usually associated with issuing a financial security backed by the returns to a loan or credit card portfolio), Thomas (1999) finds a 0.24 percent excess return on the announcement day. He attributes this increase in value to the issuer's improved ability to put assets to productive use; for example, many large financial institutions have a comparative advantage at originating loans rather than just holding them. In contrast, Lockwood, Rutherford, and Herrera (1996) use earlier data and find no statistical evidence of abnormal returns for securitizations, except for a positive announcement effect of 2.79 percent for specialized finance companies (as opposed to banks or automobile companies).

Finally, Lang, Poulsen and Stulz (1995), among others, examine the announcement effects of asset sales and find a mean abnormal return of 1.41 percent; Allen and McConnell (1998) find a positive three-day announcement effect of 1.90 percent for a sample of equity carve-outs. Both of these studies find that the positive effects are larger for firms that pay out the proceeds of these transactions either to shareholders or creditors. In contrast, they reject the idea that these sales create value by enabling firms to reallocate cash to better investment opportunities within the firm. We cannot conduct an analogous test because, as noted, we lack information about use of proceeds for a significant portion of our sample.

\footnotetext{
${ }^{51}$ The issuance of convertible debt shares some features with exchangeable securities but is more likely just another form of issuing equity. Consistent with this story, studies of convertible debt find roughly a -2.0 percent abnormal return upon announcement (see the summary in Abhyankar and Dunning, 1999).
} 
In summary, the positive announcement effect here is larger than the effect found for classic exchangeable debt or asset securitizations, but smaller than the effect found for asset sales and equity carve-outs. While the precise source of this positive reaction is unknowable, it may be that shareholders value the fact that exposure to an over-valued stock has been reduced without triggering a capital gains tax.

\section{Conclusion}

This study is the first attempt to quantify costs associated with tax-free hedging. We identify two significant frictions that burden offerings of public exchangeable offerings, but not private transactions. One disadvantage, as to which our empirical evidence is ambiguous, is that the investors may demand a discount for the relative complexity and illiquidity of these securities. This study shows that there is no short-term mispricing, but leaves open the possibility of long-term mispricing.

In addition, another key disadvantage of exchangeable securities is the market attention they attract. By announcing a hedge in advance and then implementing it all at once, as typically occurs in exchangeable securities offerings, taxpayers can expect to lose almost four percent of their appreciated stock's value. When added to a three percent underwriting fee, this cost may well exceed the economic benefit of the tax deferral. Since this extra four percent can be avoided with over-the-counter transactions, these private deals offer a significant advantage. Thus, this study sheds light on reasons why private transactions often are preferred.

Finally, the study reveals a modest but statistically significant increase in a publicly-traded taxpayer's stock price when one of these transactions is announced. This finding suggests that, in

general, the market believes the issuer's tax savings or other benefits from these transactions outweigh the issuer's costs.

In light of these three findings, it seems likely that private transactions are a greater threat to the tax base than public exchangeable offerings. Yet the public deals would remain a viable alternative for at least some taxpayers if a legal reform rendered private transactions more difficult. 


\section{References}

Abhyankar, Abhay and Alison Dunning. "Wealth Effects of Convertible Bond and Convertible Preference Share Issues: An Empirical Analysis of the UK Market." Journal of Banking \& Finance 23 (1999): 1043-1065.

Allen, Jeffrey W. and John J. McConnell. "Equity Carve-Outs and Managerial Discretion." Journal of Finance 53 (February, 1998): 163-186.

Barber, Brad M. "Exchangeable Debt.” Financial Management 22 (Summer, 1993): 48-60.

Bradford, David F. "Fixing Realization Accounting: Symmetry, Consistency and Correctness in the Taxation of Financial Instruments. Tax Law Review 50 (1995): 731-784.

Brennan, Michael J. and Avanidhar Subrahmanyam. "Market Microstructure and Asset Pricing: On the Compensation for Illiquidity in Stock Returns." Journal of Financial Economics 41 (1996): 441-464.

Brent, Averil, Dale Morse, and E. Kay Stice. "Short Interest: Explanations and Tests." Journal of Financial and Quantitative Analysis 25 (1990): 273-289.

Burnaby-Atkins, Hugh. "Convertible Bond Arbitrage Relative Value Trading." Alternative Investments Management Association Newsletter (February, 2002).

Financial Accounting Standards Board. "Accounting for Derivative Instruments and Hedging Activities." Statement of Financial Accounting Standards No. 133 (June, 1998).

Ghosh, Chinomy, and Raj Varma, and J. Randall Woolridge. "An Analysis of Exchangeable Debt Offers." Journal of Financial Economics 28 (1990): 251-263.

Hodrick, Laurie S. "Does Stock Price Elasticity Affect Corporate Financial Decisions?” Journal of Financial Economics 52 (1999): 225-256.

Holthausen, Robert, Richard Leftwich, and D. Mayers. "Large-Block Transactions: the Speed of Response and Temporary and Permanent Stock-Price Effects." Journal of Financial Economics 26 (1990): 71-95.

Hudson, Carl D., Marlin R. H. Jensen, and William N. Pugh. "Informational Versus Price-Pressure Effects: Evidence from Secondary Offerings." Journal of Financial Research 16 (1993): 193207.

Kang, Jun-Koo and Yul W. Lee. "The Pricing of Convertible Debt Offerings," Journal of Financial Economics 41 (1996): 231-248.

Lang, Larry, Annette Poulsen, and Rene Stulz. "Asset Sales, Firm Performance, and the Agency Costs of Managerial Discretion," Journal of Financial Economics 37 (1995): 3-37.

Liberty Media Corporation. Annual Report, April, 2002. 
Lockwood, Larry J., Ronald C. Rutherford, and Martin J. Herrera. "Wealth Effects of Asset Securitization.” Journal of Banking \& Finance 20 (1996): 151-164.

Mikkelson, Wayne H. and M. Megan Partch. "Stock Price Effects and Costs of Secondary Distributions.” Journal of Financial Economics 14 (1985): 165-194.

Paul, Deborah L. "Another Uneasy Compromise: The Treatment of Hedging in a Realization Income Tax." Florida Tax Review ? (1996): 1-50.

Petersen, Mitchell. "Western Southern Enterprises Case." Kellogg School of Management, Northwestern University, 2001.

Schenk, Deborah H. "Taxation of Equity Derivatives: A Partial Integration Proposal." Tax Law Review 50 No. 4 (1995): 571-641.

Schizer, David M. “Hedging Under Section 1259.” Tax Notes 80 (1998): 345-356.

Schizer, David M. "Debt Exchangeable for Common Stock: Electivity and the Tax Treatment of Issuers and Holders." Derivatives Report (March, 2000a): 10-18.

Schizer, David M. "Executives and Hedging: The Fragile Foundation of Incentive Compatibility." Columbia Law Review 100 (2000c): 440-504.

Schizer, David M. "Frictions as a Constraint on Tax Planning." Columbia Law Review 101 (2001):1312-1409.

Schizer, David M. "Sticks and Snakes: Derivatives and Curtailing Aggressive Tax Planning." Southern California Law Review 73 (2000b): 1339-1406.

Sherer, Paul M. "Alliant Energy Is Seeking to Cash in on McLeodUSA Stake with Bond Deal." Wall Street Journal (January 26, 2000).

Shleifer, Andrei. "Do Demand Curves for Stocks Slope Down?” Journal of Finance 41 (1986): 579-590.

Thomas, Hugh. "A Preliminary Look at Gains from Asset Securitization." Journal of International Financial Markets, Institutions \& Money 9 (1999): 321-333.

Warren, Alvin C. "Financial Contract Innovation and Income Tax Policy." Harvard Law Review 107 (1993): 460-492.

Weisbach, David A. "Should a Short Sale Against the Box Be a Realization Event?" National Tax Journal 50 (1997): 495-506. 


\begin{tabular}{|c|c|c|c|c|c|c|}
\hline \multicolumn{7}{|c|}{$\begin{array}{l}\text { Table 1: Illustration of the Value of Tax Deferral as a Percentage of the } \\
\text { Underlying Stock Value }\end{array}$} \\
\hline $\begin{array}{l}\text { Tax Basis as a } \\
\text { percent of current } \\
\text { value }\end{array}$ & 0 & 25 & 50 & 0 & 25 & 50 \\
\hline Discount rate & $5 \%$ & $5 \%$ & $5 \%$ & $10 \%$ & $10 \%$ & $10 \%$ \\
\hline \multicolumn{7}{|l|}{ Length of deferral } \\
\hline 3 years & 4.76 & 3.57 & 2.38 & 8.70 & 6.53 & 4.35 \\
\hline 5 years & 7.58 & 5.68 & 3.79 & 13.27 & 9.51 & 6.63 \\
\hline 10 years & 13.51 & 10.13 & 6.76 & 21.51 & 16.13 & 10.75 \\
\hline 30 years & 26.90 & 20.18 & 13.45 & 32.99 & 24.75 & 16.50 \\
\hline
\end{tabular}

Source: Authors' calculations. The table entries are the present value of tax deferral at the date of issuance of an exchangeable security expressed as a percentage of the value of the underlying stock. The calculations assume that the security hedges the entire capital gain. 


\begin{tabular}{|c|c|c|c|c|c|c|}
\hline \multicolumn{7}{|c|}{ Table 2: Security Issuance and Proceeds by Year } \\
\hline & \multicolumn{2}{|c|}{ All Issues } & \multicolumn{2}{|c|}{ Public Issuers } & \multicolumn{2}{|c|}{ Private Issuers } \\
\hline Year & Number & $\begin{array}{c}\text { Gross } \\
\text { Proceeds }\end{array}$ & Number & $\begin{array}{c}\text { Gross } \\
\text { Proceeds }\end{array}$ & Number & $\begin{array}{c}\text { Gross } \\
\text { Proceeds }\end{array}$ \\
\hline 1993 & 1 & 0.77 & 1 & 0.77 & 0 & 0 \\
\hline 1994 & 3 & 1.11 & 3 & 1.11 & 0 & 0 \\
\hline 1995 & 10 & 1.92 & 8 & 1.30 & 2 & 0.61 \\
\hline 1996 & 5 & 0.83 & 1 & 0.05 & 4 & 0.78 \\
\hline 1997 & 9 & 2.92 & 4 & 1.52 & 5 & 1.41 \\
\hline 1998 & 8 & 2.86 & 2 & 1.64 & 6 & 1.22 \\
\hline 1999 & 16 & 8.96 & 11 & 7.93 & 5 & 1.03 \\
\hline 2000 & 7 & 3.50 & 5 & 2.29 & 2 & 1.21 \\
\hline 2001 & 2 & 1.37 & 2 & 1.37 & 0 & 0 \\
\hline TOTAL & 61 & 24.39 & 37 & 17.98 & 24 & 6.26 \\
\hline
\end{tabular}

Gross proceeds are in billions of dollars. 


\begin{tabular}{|l|c|c|c|c|c|}
\hline \multicolumn{7}{|c|}{ Table 3: Summary Statistics } \\
\hline Variable / Sample & Number & Median & Mean & Minimum & Maximum \\
\hline Offering Amount & & & & & \\
\hline All Issuers & 61 & $\$ 224 \mathrm{~m}$ & $\$ 397 \mathrm{~m}$ & $\$ 12.5 \mathrm{~m}$ & $\$ 1,510 \mathrm{~m}$ \\
\hline Public Issuers & 37 & $\$ 341 \mathrm{~m}$ & $\$ 486 \mathrm{~m}$ & $\$ 12.5 \mathrm{~m}$ & $\$ 1,510 \mathrm{~m}$ \\
\hline Private Issuers & 24 & $\$ 207 \mathrm{~m}$ & $\$ 260 \mathrm{~m}$ & $\$ 73.2 \mathrm{~m}$ & $\$ 1,000 \mathrm{~m}$ \\
\hline Size Relative to the Issuer's Equity Value & & \\
\hline Public Issuers & 37 & $2.64 \%$ & $9.06 \%$ & $0.29 \%$ & $103.9 \%$ \\
\hline Size Relative to the Value of Underlying Stock & & & \\
\hline All Issuers & 60 & $4.24 \%$ & $7.11 \%$ & $0.31 \%$ & $43.75 \%$ \\
\hline Public Issuers & 36 & $4.14 \%$ & $7.95 \%$ & $0.31 \%$ & $43.75 \%$ \\
\hline Private Issuers & 24 & $4.24 \%$ & $5.79 \%$ & $0.83 \%$ & $25.09 \%$ \\
\hline Underwriting Fee, Relative to Proceeds & & & \\
\hline All Issuers & 53 & $3.0 \%$ & $2.80 \%$ & $2.0 \%$ & $3.5 \%$ \\
\hline Public Issuers & 30 & $3.0 \%$ & $2.72 \%$ & $2.0 \%$ & $3.5 \%$ \\
\hline Private Issuers & 23 & $3.0 \%$ & $3.01 \%$ & $2.96 \%$ & $3.25 \%$ \\
\hline
\end{tabular}

Source: Authors' calculations. Data on underwriting fees are unavailable for some transactions. 


\begin{tabular}{|c|c|c|c|c|}
\hline \multicolumn{5}{|c|}{$\begin{array}{c}\text { Table 4: Returns for Underlying Stocks around Anno } \\
\text { Days }\end{array}$} \\
\hline \multicolumn{5}{|c|}{ Panel A: Average Abnormal Returns from Market Model } \\
\hline 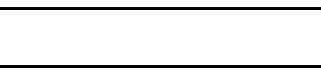 & \multicolumn{2}{|c|}{ Announcement Day } & \multicolumn{2}{|c|}{ Filing Day } \\
\hline & $\begin{array}{c}\text { Abnormal } \\
\text { Return }\end{array}$ & t-statistic & $\begin{array}{c}\text { Abnormal } \\
\text { Return }\end{array}$ & t-statistic \\
\hline Event - 5 days & -0.049 & $(-0.15)$ & -0.060 & $(-0.13)$ \\
\hline Event - 4 days & 0.44 & $(1.38)$ & 0.13 & $(0.23)$ \\
\hline Event - 3 days & 0.096 & $(0.26)$ & 0.40 & $(0.83)$ \\
\hline Event - 2 days & -0.085 & $(-0.20)$ & 0.70 & $(1.46)$ \\
\hline Event - 1 day & -0.21 & $(-0.54)$ & -0.95 & $(-2.62)$ \\
\hline Event day & -0.51 & $(-1.13)$ & -2.38 & $(-4.20)$ \\
\hline Event +1 day & -0.44 & $(-1.17)$ & 0.58 & $(1.33)$ \\
\hline Event +2 days & -0.67 & $(-1.45)$ & 0.30 & $(0.73)$ \\
\hline Event +3 days & -0.11 & $(-0.26)$ & 0.024 & $(0.06)$ \\
\hline Event +4 days & 0.60 & $(1.51)$ & 0.55 & $(1.37)$ \\
\hline Event +5 days & 0.38 & $(0.91)$ & -0.14 & $(-0.49)$ \\
\hline \multicolumn{5}{|c|}{ Panel B: Median Abnormal Returns and Percent Positive } \\
\hline & \multicolumn{2}{|c|}{ Announcement Day } & \multicolumn{2}{|c|}{ Filing Day } \\
\hline & $\begin{array}{c}\text { Abnormal } \\
\text { Return }\end{array}$ & $\begin{array}{l}\text { Percent } \\
\text { Positive }\end{array}$ & $\begin{array}{l}\text { Abnormal } \\
\text { Return }\end{array}$ & $\begin{array}{l}\text { Percent } \\
\text { Positive }\end{array}$ \\
\hline Event -5 days & -0.23 & 43.3 & -0.58 & 46.7 \\
\hline Event - 4 days & 0.031 & 51.7 & -0.041 & 50.0 \\
\hline Event - 3 days & 0.073 & 53.3 & -0.010 & 50.0 \\
\hline Event - 2 days & -0.38 & 43.3 & 0.33 & 55.0 \\
\hline Event - 1 day & -0.16 & 48.3 & -1.29 & 30.0 \\
\hline Event day & -0.55 & 45.0 & -2.15 & 20.0 \\
\hline Event +1 day & -0.50 & 36.7 & 0.27 & 53.3 \\
\hline Event +2 days & -0.75 & 40.0 & 0.29 & 62.3 \\
\hline Event +3 days & -0.42 & 43.3 & -0.065 & 47.5 \\
\hline Event +4 days & 0.18 & 56.7 & 0.18 & 54.1 \\
\hline Event +5 days & 0.36 & 60.0 & 0.061 & 45.9 \\
\hline
\end{tabular}

Excess returns are listed as percentages; t-statistics are in parentheses. The sample has 61 deals. The excess returns are calculated using a market model. For the percent positive, given the sample size, the 95 percent confidence interval around the null hypothesis of 50.0 percent positive is $[37.4 \%, 62.6 \%]$. 


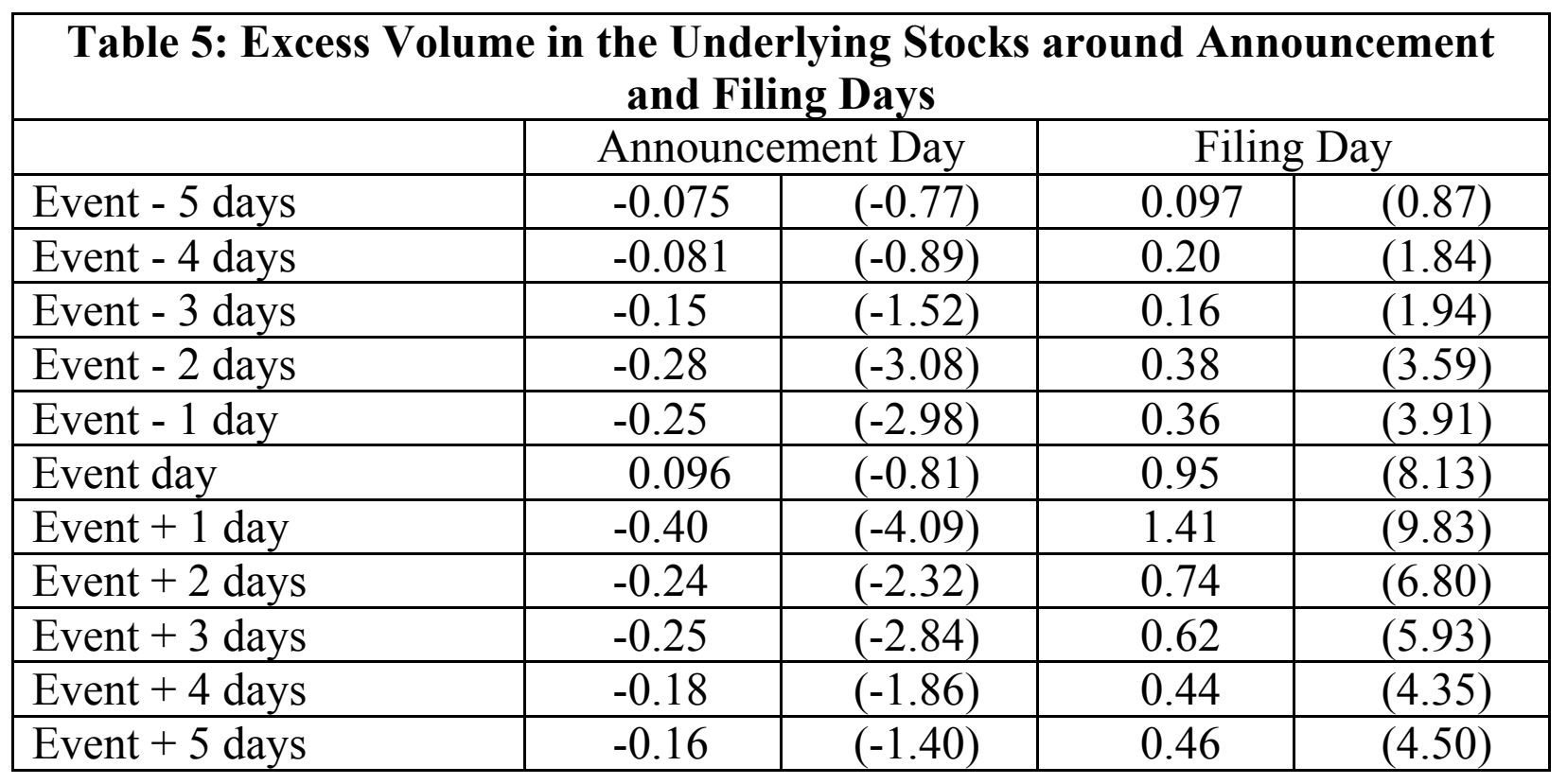

Excess volume is listed as a fraction; t-statistics are in parentheses. The sample has 61 deals for which the underlying stock is publicly traded. Excess volume is calculated by regressing log volume on log shares outstanding for the underlying stock, a transaction-specific constant that allows each firm to have its own average volume, transaction-specific sensitivities to market volume, and dummy variables for each of the days in the two event windows. 


\begin{tabular}{|l|c|c|c|c|}
\hline \multicolumn{5}{|c|}{ Table 6: Returns for Issuer around Announcement Date } \\
\hline & $\begin{array}{c}\text { Average } \\
\text { Abnormal } \\
\text { Return }\end{array}$ & $\begin{array}{c}\text { Median } \\
\text { tbnormal } \\
\text { Return }\end{array}$ & $\begin{array}{c}\text { Percent } \\
\text { Positive }\end{array}$ \\
\hline Event - 5 days & -0.48 & $(-1.12)$ & -0.23 & 40.5 \\
\hline Event - 4 days & 0.080 & $(0.19)$ & -0.13 & 40.5 \\
\hline Event - 3 days & 0.47 & $(1.12)$ & -0.25 & 45.9 \\
\hline Event - 2 days & 0.68 & $(1.60)$ & -0.15 & 48.6 \\
\hline Event - 1 day & -0.35 & $(-0.82)$ & -0.36 & 40.5 \\
\hline Event day & 0.88 & $(2.08)$ & 0.47 & 62.2 \\
\hline Event + 1 day & 0.27 & $(0.63)$ & -0.37 & 40.5 \\
\hline Event + 2 days & -0.23 & $(-0.54)$ & -0.056 & 48.6 \\
\hline Event + 3 days & 0.065 & $(0.15)$ & -0.12 & 45.9 \\
\hline Event + 4 days & -0.35 & $(-0.83)$ & -0.33 & 29.7 \\
\hline Event + 5 days & -0.13 & $(-0.31)$ & -0.041 & 48.6 \\
\hline Residual on underlying & 0.061 & $(8.85)$ & & \\
\hline Residual on underlying * & -0.020 & $(-2.39)$ & & \\
\hline After issuance dummy & & & & \\
\hline After issuance dummy & -0.0008 & $(-1.23)$ & & \\
\hline
\end{tabular}

Excess returns are listed as percentages; $t$-statistics are in parentheses. The sample has 37 deals. The excess returns are calculated using a market model. For the percent positive, given the sample size, the 95 percent confidence interval around the null hypothesis of 50.0 percent positive is $[33.8 \%, 66.2 \%]$. 


\section{Appendix A: List of Transactions}

Issuer: American Express

Security type:

Issue date:
Underlying stock:

Offering amount:

Maturity date:
First Data Corp.

$\$ 771.8 \mathrm{~m}$.

$10 / 15 / 96$

Details of acquisition of underlying: Prior to April 1992, First Data was a wholly-owned subsidiary of American Express. In April 1992, American Express had an initial public offering and retained 55 percent of First Data's stock. In March 1993, American Express made a secondary offering of First Data stock, after which American Express owned 22 percent of First Data's stock.

Issuer:

First Chicago

Underlying stock:

NEXTEL

Security type:

DECS

Offering amount:

$\$ 235.6 \mathrm{~m}$.

Issue date:

2/8/94

Maturity date:

$2 / 15 / 97$

Details of acquisition of underlying: First Chicago made a venture capital investment in NEXTEL.

Issuer: $\quad$ ARCO

Underlying stock: $\quad$ Lyondell

Security type: $\quad$ Exchangeable Notes

Issue date:

$8 / 1 / 94$

Offering amount:

$\$ 866.3 \mathrm{~m}$.

Maturity date:

9/15/97

Details of acquisition of underlying: Prior to 1989, Lyondell was first a division and than a wholly-owned subsidiary of ARCO. ARCO took Lyondell public in 1989. As of August 1994, ARCO owned 49.9 percent of Lyondell's stock (39.9 million shares). The exchangeable notes may be exchanged into as many as 39.9 million shares.

$\begin{array}{llll}\text { Issuer: } & \text { Pier 1 } & \text { Underlying stock: } & \text { General Host } \\ \text { Security type: } & \text { Exch Debentures } & \text { Offering amount: } & \$ 12.5 \mathrm{~m} . \\ \text { Issue date: } & 12 / 5 / 94 & \text { Maturity date: } & 12 / 1 / 00\end{array}$

Details of acquisition of underlying: In April 1993, Pier 1 acquired over 2 million shares of General Host from the sale of its 49.5 percent interest in Sunbelt Nursery Group. Pier 1 bought Sunbelt Nursery from Tandy Corporation in 1975, after which Sunbelt Nursery was a wholly-owned subsidiary of Pier 1. In 1985, Pier 1 split into three companies and Sunbelt Nursery became a separately-traded entity. In September 1990, Pier 1 purchased 50.4 percent of Sunbelt Nursery from Pier 1's largest shareholder, Intermark Incorporated, at the price of $\$ 12$ per share. In November 1990, Pier 1 completed an acquisition of the remaining shares in the firm for $\$ 12$ per share. In October 1991, Pier 1 sold 40.2 percent of Sunbelt Nursery's stock to the public at $\$ 8.50$ per share; it further reduced its stake in Sunbelt Nursery in 1992.

Issuer:

Sprint

Underlying stock:

SNET

Security type:

DECS

Offering amount:

$\$ 124.3 \mathrm{~m}$.

Issue date:

3/20/95

Maturity date:

$3 / 31 / 00$

Details of acquisition of underlying: Sprint acquired SNET stock from AT\&T in the early 1980s.

Issuer:

Security type:

Allstate Corporation

Underlying stock:

Offering amount:

PMI Group

Issue date:

Exchangeable Notes

Maturity date:

$\$ 340.5 \mathrm{~m}$.

4/10/95

$4 / 15 / 98$

Details of acquisition of underlying: Prior to the transaction, PMI was a wholly-owned subsidiary of Allstate. The DECS-like exchangeable notes were issued concurrently with the initial public offering of PMI. The DECS represented 38.6 percent of the stock of PMI.
Issuer:
Merrill Lynch
Underlying stock:
MGIC Invst Co.
Security type:
STRYPES
$7 / 20 / 95$
Offering amount:
$\$ 240.0 \mathrm{~m}$.
Maturity date:
$8 / 15 / 98$

Details of acquisition of underlying: This deal monetized half of Northwestern Mutual's stake in MGIC Investment Corp. In 1984, Northwestern Mutual Life acquired 90 percent of MGIC's equity in a management buyout for MGIC from its parent, Baldwin-United. Northwestern Mutual Life invested \$250 million. MGIC went public in 1991 with Northwestern Mutual Life selling shares that reduced its stake in 
MGIC to 61 percent. Subsequent secondary offerings reduced Northwestern Mutual Life's ownership stake to 20 percent.

$\begin{array}{llll}\text { Issuer: } & \text { Houghton Mifflin } & \text { Underlying stock: } & \text { INSO Corp. } \\ \text { Security type: } & \text { SAILS } & \text { Offering amount: } & \$ 119.0 \mathrm{~m} . \\ \text { Issue date: } & 7 / 27 / 95 & \text { Maturity date: } & 8 / 1 / 99\end{array}$

Details of acquisition of underlying: InfoSoft (later renamed INSO) began operations as a wholly-owned subsidiary of Houghton-Mifflin in 1982. In March 1994, Houghton Mifflin sold 60.4 percent of its stake in INSO through an IPO. Concurrent with the SAILS offering, a secondary offering of INSO stock sold 600,000 of Houghton Mifflin's shares in INSO, which reduced Houghton Mifflin's position to 35.9 percent.

$\begin{array}{llll}\text { Issuer: } & \text { Time Warner Trust } & \text { Underlying stock: } & \text { HASBRO, Inc. } \\ \text { Security type: } & \text { PERCS } & \text { Offering amount: } & \$ 373.8 \mathrm{~m} . \\ \text { Issue date: } & 8 / 9 / 95 & \text { Maturity date: } & 12 / 23 / 97\end{array}$

Details of acquisition of underlying: Time Warner acquired Hasbro stock in 1983 both through exchanges for businesses and direct purchases or shares.

$\begin{array}{llll}\text { Issuer: } & \text { Laidlaw One } & \text { Underlying stock: } & \text { US Filter } \\ \text { Security type: } & \text { Exchangeable Notes } & \text { Offering amount: } & \$ 63.0 \mathrm{~m} . \\ \text { Issue date: } & 11 / 22 / 95 & \text { Maturity date: } & 12 / 31 / 00\end{array}$

Details of acquisition of underlying: Laidlaw acquired the shares in US Filter in September 1994 as a result of the sale of its interest in its former Italian water engineering firm.

$\begin{array}{llll}\text { Issuer: } & \text { Jefferson Pilot } & \text { Underlying stock: } & \text { NationsBank } \\ \text { Security type: } & \text { ACES } & \text { Offering amount: } & \$ 119.6 \mathrm{~m} . \\ \text { Issue date: } & 11 / 27 / 95 & \text { Maturity date: } & 1 / 21 / 00\end{array}$

Details of acquisition of underlying: Jefferson Pilot's equity position in Nationsbank was the largest position in its equity portfolio. It is unclear when Jefferson Pilot acquired Nationsbank stock. Jefferson Pilot used the proceeds to retire debt associated with its acquisition of the Alexander Hamilton Life Insurance Company.

Issuer:

US WEST

Underlying stock:

Enhance Fin Svs

Security type:

DECS Offering amount: $\$ 117.6 \mathrm{~m}$.

Issue date: $12 / 6 / 95$

Maturity date: $12 / 15 / 98$

Details of acquisition of underlying: In May 1988, US West purchased 20.3 percent of Enhance Financial Services Inc. and 21.7 percent of Securities Guaranty Inc. for \$50 million.

$\begin{array}{llll}\text { Issuer: } & \text { Enron Corp. } & \text { Underlying stock: } & \text { Enron Oil \& Gas } \\ \text { Security type: } & \text { Exch Notes } & \text { Offering amount: } & \$ 217.5 \mathrm{~m} . \\ \text { Issue date: } & 12 / 8 / 95 & \text { Maturity date: } & 12 / 13 / 98\end{array}$

Details of acquisition of underlying: These exchangeable notes were part of Enron's plan to divest part of its position in Enron Oil \& Gas, of which it owned 53 percent before the transaction. Enron Oil \& Gas concurrently announced a secondary equity issue in which Enron would sell 21.6 million shares of Enron Oil \& Gas. Before its initial public offering in 1989, Enron Oil \& Gas was a wholly owned subsidiary of Enron Corporation.
Issuer:
Cooper Industries
Underlying stock:
Wyman-Gordon
Security type:
DECS
Issue date:
$12 / 14 / 95$
Offering amount:
Maturity date:
$\$ 202.5 \mathrm{~m}$.
$1 / 1 / 99$

Details of acquisition of underlying: In May 1994, Cooper acquired shares in Wyman-Gordon in exchange for its common stock of Cameron Forged Products Company.

Issuer:

Security type:

Issue date:
Times Mirror

PEPS

$3 / 13 / 96$
Underlying stock:

Offering amount:

Maturity date:
Netscape

$\$ 51.2 \mathrm{~m}$.

$3 / 15 / 01$ 
Details of acquisition of underlying: In April 1995, Times Mirror invested $\$ 4$ million in Netscape Communications (before its IPO). At the time of the offering, this position was worth $\$ 92$ million.

Issuer:

Security type:

Issue date:
Underlying stock:

Offering amount:

Maturity date:
Cox Commun

$\$ 194.4 \mathrm{~m}$.

$6 / 1 / 99$

Details of acquisition of underlying: Cox Enterprises, the privately-held majority owner of Cox

Communications, issued a private security with Merrill Lynch to monetize a small portion of its position in Cox Communications.

$\begin{array}{llll}\text { Issuer: } & \text { Merrill Lynch } & \text { Underlying stock: } & \text { SunAmerica } \\ \text { Security type: } & \text { STRYPES } & \text { Offering amount: } & \$ 169.1 \mathrm{~m} . \\ \text { Issue date: } & 6 / 6 / 96 & \text { Maturity date: } & 6 / 15 / 99\end{array}$

Details of acquisition of underlying: Mr. Broad was the chairman and chief executive officer of SunAmerica. His position in the company had grown over time due to executive compensation programs.

$\begin{array}{llll}\text { Issuer: } & \text { Merrill Lynch } & \text { Underlying stock: } & \text { IMC Global } \\ \text { Security type: } & \text { STRYPES } & \text { Offering amount: } & \$ 216.5 \mathrm{~m} . \\ \text { Issue date: } & 7 / 2 / 96 & \text { Maturity date: } & 7 / 1 / 01\end{array}$

Details of acquisition of underlying: GAMI, a privately-owned company whose chair is Sam Zell, obtained shares in IMC Global when IMC Global acquired Vigoro Corporation in November 1995. GAMI had owned 20 percent of Vigoro; after the merger, GAMI held seven percent of IMC Global's stock. Mr. Zell helped create Vigoro by buying other firm's assets on the cheap. At the time of the merger, Vigoro stock was selling at more than four times the price at its 1991 initial public offering.

$\begin{array}{llll}\text { Issuer: } & \text { Salomon Inc. } & \text { Underlying stock: } & \text { Cincinnati Bell } \\ \text { Security type: } & \text { DECS } & \text { Offering amount: } & \$ 195.1 \mathrm{~m} . \\ \text { Issue date: } & 11 / 14 / 96 & \text { Maturity date: } & 2 / 1 / 01\end{array}$

Details of acquisition of underlying: Western and Southern Life Insurance began acquiring Cincinnati Bell stock in 1983. A significant portion of their investment came from the conversion of convertible preferred shares that had a conversion price of $\$ 16$. When the exchangeable debt was issued, Cincinnati Bell's share price was $\$ 50$.

Issuer:

Security type:

Issue date:
Worthington

DECS

2/27/97
Underlying stock: Offering amount:

Maturity date:
Rouge Steel

$\$ 81.3 \mathrm{~m}$.

$3 / 1 / 00$

Details of acquisition of underlying: Rouge Steel was started in the 1920s as a subsidiary of Ford Motor Company. Ford sold 80 percent of Rouge Steel in a leveraged buyout in 1989. The buyers in 1989 were Carl Valdiserri, Worthington Steel, and Chase Manhattan Capital. In 1992, Rouge bought out Ford's remaining 20 percent stake. In 1994, Rouge held an initial public offering at which point Chase Manhattan Capital sold its shares.

$\begin{array}{llll}\text { Issuer: } & \text { Nextel Trust } & \text { Underlying stock: } & \text { Nextel Commun } \\ \text { Security type: } & \text { STRYPES } & \text { Offering amount: } & \$ 100.3 \mathrm{~m} . \\ \text { Issue date: } & 3 / 4 / 97 & \text { Maturity date: } & 5 / 15 / 00\end{array}$

Details of acquisition of underlying: This trust-based deal is based on Nextel shares owned by two investment vehicles owned by Telecom Ventures. Telecom Ventures is a private equity firm.

$\begin{array}{llll}\text { Issuer: } & \text { ACES Trust II } & \text { Underlying stock: } & \text { Republic Industries } \\ \text { Security type: } & \text { TRACES } & \text { Offering amount: } & \$ 207.7 \mathrm{~m} . \\ \text { Issue date: } & 5 / 29 / 97 & \text { Maturity date: } & 5 / 15 / 00\end{array}$

Details of acquisition of underlying: This trust-based deal is based on Republic Industries shares owned by a group of 14 different shareholders. The contracting shareholders are a mix of corporate and individual investors; however, some of the backing shares come from trusts or IRA accounts. 


$\begin{array}{llll}\text { Issuer: } & \text { Houston Ind } & \text { Underlying stock: } & \text { Time Warner } \\ \text { Security type: } & \text { ACES } & \text { Offering amount: } & \$ 918.8 \mathrm{~m} . \\ \text { Issue date: } & 7 / 9 / 97 & \text { Maturity date: } & 7 / 1 / 00\end{array}$

Details of acquisition of underlying: In 1995, Houston Industries received Time Warner stock as part of the consideration in the sale of its cable television business to Time Warner.

Issuer: Ralston Purina Underlying stock: Interstate Bakeries

Security type: $\quad$ SAILS Offering amount: $\$ 420 \mathrm{~m}$.

Issue date: $\quad$ 7/23/97 $\quad$ Maturity date:

Details of acquisition of underlying: In July 1995, Ralston Purina received shares of International Baking

Company as part of the consideration for its wholly-owned subsidiary, Continental Baking Company.

Issuer: $\quad$ Mand Exch Trust (Banc One) Underlying stock:FIRSTPLUS Financial

Security type: $\quad$ TIMES $\quad$ Offering amount: $\quad \$ 97.8 \mathrm{~m}$.

Issue date: 9/12/97 Maturity date: 8/15/00

Details of acquisition of underlying: Financial press accounts report that Banc One's basis in its FirstPlus

Financial Group stock is about $\$ 7$ per share (compared to a share price of $\$ 48$ when the security was issued).

It is unclear how Banc One, an investment bank, acquired the FirstPlus stock; however, a portion of the position in non-voting convertible stock (which can be converted only by a shareholder other than Banc One) so it is unlikely that the entire position was purchased in market transactions.

$\begin{array}{llll}\text { Issuer: } & \text { Snyder Trust } & \text { Underlying stock: } & \text { Snyder Comm } \\ \text { Security type: } & \text { STRYPES } & \text { Offering amount: } & \$ 116.2 \mathrm{~m} . \\ \text { Issue date: } & 9 / 18 / 97 & \text { Maturity date: } & 11 / 15 / 00\end{array}$

Details of acquisition of underlying: In this trust-based deal, the Snyder family (including Daniel Snyder, the CEO of Snyder Communications) and other large (presumably inside) investors were the shareholders whose shares backed the STRYPES Trust. At the same time as the STRYPES issue, Snyder Communications raised money by issuing equity and other large shareholders sold stock in a secondary offering.

Issuer:

DECS Trust

Underlying stock:

DIMON Inc

Security type:

DECS

Offering amount:

$\$ 73.2 \mathrm{~m}$.

Issue date:

9/25/97

Maturity date:

$8 / 15 / 00$

Details of acquisition of underlying: In this trust-based deal, the Monk family backed the 3.1 million shares of DIMON stock in the DECS trust. At the same time, the family sold 1.8 million shares of DIMON stock in a secondary offering. The family had obtained the shares in the April 1995 merger of Dibrell Brothers, Incorporate and Monk-Austin, Incorporated.

$\begin{array}{llll}\text { Issuer: } & \text { WBK Trust } & \text { Underlying stock: } & \text { Westpac } \\ \text { Security type: } & \text { STRYPES } & \text { Offering amount: } & \$ 909.2 \mathrm{~m} \text {. } \\ \text { Issue date: } & 9 / 30 / 97 & \text { Maturity date: } & 11 / 15 / 00\end{array}$

Details of acquisition of underlying: AMP Society (an Australian financial services and insurance company) backed this trust-based STRYPES issue. Westpac Banking is an Australian bank but has ADRs that trade on the NYSE. AMP and Westpac formed a strategic alliance in 1990 which resulted in AMP owning 14.9 percent of Westpac's stock. The strategic alliance was dissolved in 1995.

$\begin{array}{llll}\text { Issuer: } & \text { Merrill Lynch } & \text { Underlying stock: } & \text { CIBER, Inc. } \\ \text { Security type: } & \text { STRYPES } & \text { Offering amount: } & \$ 94.7 \mathrm{~m} . \\ \text { Issue date: } & 1 / 26 / 98 & \text { Maturity date: } & 2 / 1 / 01\end{array}$

Details of acquisition of underlying: Bobby G. Stevenson, chairman and chief executive officer of CIBER, backed Merrill Lynch's issuance of the STRYPES. As of December 31, 1997, Stevenson owned approximately 27 percent of CIBER's stock. The STRYPES represent about one-third of his stake in the firm.

Issuer: $\quad$ Reader's Dig Trust $\quad$ Underlying stock: Reader's Dig Assn 
Security type:

TRACES

Offering amount:

$\$ 241.6 \mathrm{~m}$.

Issue date: $2 / 10 / 98$

Maturity date:

$2 / 15 / 01$

Details of acquisition of underlying: This trust-based transaction enabled six charitable organizations to monetize a portion of their Reader's Digest common stock in a public hybrid equity offering. Before Reader's Digest went public in 1990, Reader's Digest stock was a substantial portion of these six organizations' investments. Notably, two other charitable organizations did not participate in the TRACES. The TRACES allowed the organizations to continue the diversification strategies that they began when Reader's Digest went public. The deferral of capital gains taxes is probably not the motive for this transaction since the charitable organizations are tax exempt.

$\begin{array}{llll}\text { Issuer: } & \text { DECS Trust III } & \text { Underlying stock: } & \text { Herbalife Intl } \\ \text { Security type: } & \text { DECS } & \text { Offering amount: } & \$ 115.0 \mathrm{~m} . \\ \text { Issue date: } & 3 / 25 / 98 & \text { Maturity date: } & 2 / 15 / 01\end{array}$

Details of acquisition of underlying: This trust-based transaction was backed by Mark Hughes, founder and president of Herbalife International.

$\begin{array}{llll}\text { Issuer: } & \text { CVS ACES Trust } & \text { Underlying stock: } & \text { CVS Corporation } \\ \text { Security type: } & \text { TRACES } & \text { Offering amount: } & \$ 223 \mathrm{~m} . \\ \text { Issue date: } & 5 / 21 / 98 & \text { Maturity date: } & 5 / 15 / 01\end{array}$

Details of acquisition of underlying: In this trust-based transaction, Eugene Applebaum backed the transaction. Mr. Applebaum acquired his CVS shares as part of the merger of CVS and Arbor Drugs in March 1998. The stock-for-stock transaction was valued at $\$ 1.48$ billion. Mr. Applebaum founded Arbor Drugs with a single store in 1962. He was appointed to the Board of Directors of CVS after the merger.

$\begin{array}{llll}\text { Issuer: } & \text { Dollar Gen Trust } & \text { Underlying stock: } & \text { Dollar General } \\ \text { Security type: } & \text { STRYPES } & \text { Offering amount: } & \$ 295.8 \mathrm{~m} . \\ \text { Issue date: } & 5 / 21 / 98 & \text { Maturity date: } & 5 / 15 / 01\end{array}$

Details of acquisition of underlying: In this trust-based transaction, Cal Turner, chairmen and CEO of Dollar General, backed the transaction. At the exchange date, the shares in the transaction could reduce the Turner family's stake in Dollar General from 23 percent to 18 percent.

Issuer:

Security type:

Issue date: Estee Lauder Trust TRACES 6/21/98
Underlying stock: Offering amount: Maturity date:
Estee Lauder

$\$ 248.1 \mathrm{~m}$.

$6 / 5 / 01$

Details of acquisition of underlying: In this trust-based transaction, shares owned by members of the Lauder family backed the transaction.

Issuer: $\quad$ Tribune Co.

Security type: $\quad$ DECS

Issue date: $\quad 7 / 30 / 98$

Underlying stock: $\quad$ Learning Co. Offering amount: $\quad \$ 128.5 \mathrm{~m}$.

Maturity date: $\quad 8 / 15 / 98$

Details of acquisition of underlying: In December 1995, Tribune acquired shares in the Learning Company in exchange for its former wholly-owned subsidiaries, Compton's NewMedia and Compton's Learning Company. Tribune had acquired Compton's from Encyclopedia Britannica in July 1993 for $\$ 57$ million in cash.
Issuer:
MediaOne
Underlying stock:
AirTouch
Security type:
DECS
2/9/99
Offering amount:
$\$ 162.5 \mathrm{~m}$.
Issue date:
Maturity date:
$2 / 15 / 02$

Details of acquisition of underlying: In April 1988, MediaOne sold its wireless communications business to AirTouch for shares of AirTouch stock.

Issuer:

Security type:

Issue date:
DECS Trust IV

DECS

2/9/99
Underlying stock:

Offering amount:

Maturity date:
Maxtor Corp.

$\$ 162.5 \mathrm{~m}$.

2/15/02 
Details of acquisition of underlying: Maxtor announced a secondary offering. The company sold 7.8 million shares and Hyundai Electronics America sold 3.2 million shares. In addition, through a trust-based transaction, Hyundai backed exchangeable debt that could result in selling another 12.5 million shares. Hyundai acquired the Maxtor stock in August 1993 as part of a strategic alliance between the two firms. Hyundai invested $\$ 150$ million in Maxtor in exchange for 19.4 million Maxtor shares (a price of $\$ 7.70$ per share), representing 40 percent of Maxtor's shares. In November 1995, Maxtor accepted Hyundai's bid to buy the rest of the company for $\$ 6.70$ per share. In June 1998, Hyundai sold Maxtor shares to the public in an initial public offering.

$\begin{array}{llll}\text { Issuer: } & \text { Estee Lauder Trust II } & \text { Underlying stock: } & \text { Estee Lauder } \\ \text { Security type: } & \text { TRACES } & \text { Offering amount: } & \$ 150.0 \mathrm{~m} . \\ \text { Issue date: } & 2 / 17 / 99 & \text { Maturity date: } & 2 / 23 / 02\end{array}$

Details of acquisition of underlying: In this trust-based transaction, shares owned by members of the Lauder family backed the transaction.

$\begin{array}{llll}\text { Issuer: } & \text { Comcast } & \text { Underlying stock: } & \text { AT\&T } \\ \text { Security type: } & \text { PHONES } & \text { Offering amount: } & \$ 718.3 \mathrm{~m} . \\ \text { Issue date: } & 3 / 11 / 99 & \text { Maturity date: } & 5 / 15 / 29\end{array}$

Details of acquisition of underlying: Comcast received AT\&T shares in AT\&T's March 1999 acquisition of TCI. Comcast acquired its stock in TCI through various partnerships and joint ventures.

$\begin{array}{llll}\text { Issuer: } & \text { Tribune Co. } & \text { Underlying stock: } & \text { America Online } \\ \text { Security type: } & \text { PHONES } & \text { Offering amount: } & \$ 1.1 \mathrm{~b} . \\ \text { Issue date: } & 4 / 7 / 99 & \text { Maturity date: } & 5 / 15 / 29\end{array}$

Details of acquisition of underlying: In October 1991, the Tribune Company took a minority position in AOL, which was then a privately-held company; it bought 512,000 shares for $\$ 5$ million (a price of less than $\$ 10$ per share). Given AOL's three subsequent two-for-one splits, this $\$ 5$ million position represents over half of the 7 million AOL shares owned by Tribune at the issuance of the PHONES. AOL's share price was $\$ 157$ when the PHONES were issued.

$\begin{array}{llll}\text { Issuer: } & \text { Amdocs Trust } & \text { Underlying stock: } & \text { Amdocs Ltd } \\ \text { Security type: } & \text { TRACES } & \text { Offering amount: } & \$ 224.4 \mathrm{~m} . \\ \text { Issue date: } & 6 / 7 / 99 & \text { Maturity date: } & 6 / 11 / 02\end{array}$

Details of acquisition of underlying: This trust-based transaction was backed by inside shareholders. The TRACES represented 10 million shares. At the same time, Amdocs announced a secondary offering by existing shareholders of 18 million shares and the company issued 2 million new shares.

$\begin{array}{llll}\text { Issuer: } & \text { Southwest Sec Gp } & \text { Underlying stock: } & \text { Knight/Trimark Gp } \\ \text { Security type: } & \text { DARTS } & \text { Offering amount: } & \$ 50.0 \mathrm{~m} . \\ \text { Issue date: } & 6 / 11 / 99 & \text { Maturity date: } & 6 / 30 / 04\end{array}$

Details of acquisition of underlying: In May 1997, Roundtable Partners transformed itself from a private company owned by management and 27 broker-dealers into Knight/Trimark, a public company. In addition to raising capital through the initial public offering, the broker-dealers, including Southwest Securities, received shares in Knight/Trimark.

$\begin{array}{llll}\text { Issuer: } & \text { Kerr-McGee } & \text { Underlying stock: } & \text { Devon Energy } \\ \text { Security type: } & \text { DECS } & \text { Offering amount: } & \$ 287.3 \mathrm{~m} . \\ \text { Issue date: } & 7 / 27 / 99 & \text { Maturity date: } & 8 / 2 / 04\end{array}$

Details of acquisition of underlying: In October 1996, Kerr-McGee acquired stock in Devon Energy in exchange for its North American onshore oil and gas fields.

Issuer:

Security type:

Issue date:
DECS Trust V

DECS

8/6/99
Underlying stock:

Offering amount:

Maturity date:
Crown Castle

$\$ 95.6 \mathrm{~m}$.

$8 / 15 / 02$ 
Details of acquisition of underlying: This trust-based transaction was backed by Robert Crown, a nonexecutive board member in Crown Castle. Before 1998, Mr. Crown had operational responsibilities at the firm.

$\begin{array}{llll}\text { Issuer: } & \text { Enron Corp. } & \text { Underlying stock: } & \text { Enron Oil \& Gas } \\ \text { Security type: } & \text { Exch Notes } & \text { Offering amount: } & \text { \$222.5 m. } \\ \text { Issue date: } & 8 / 10 / 99 & \text { Maturity date: } & 7 / 31 / 02\end{array}$

Details of acquisition of underlying: Before its initial public offering in 1989, Enron Oil \& Gas was a wholly-owned subsidiary of Enron Corporation. In July 1999, Enron announced that it would exchange 62 million of its 82 million Enron Oil \& Gas (EOG) shares for EOG's interest in several foreign investments. After this transaction, EOG would be renamed EOG Resources. To dispose of its remaining EOG shares, Enron offered some shares in a secondary offering concurrent to the issuance of the exchangeable debt.

$\begin{array}{llll}\text { Issuer: } & \text { Reliant Energy } & \text { Underlying stock: } & \text { Time Warner } \\ \text { Security type: } & \text { ZENS } & \text { Offering amount: } & \$ 1.0 \mathrm{~b} \text {. } \\ \text { Issue date: } & 9 / 15 / 99 & \text { Maturity date: } & 9 / 15 / 29\end{array}$

Details of acquisition of underlying: In 1995, Houston Industries received Time Warner stock as part of the consideration in the sale of its cable television business to Time Warner.

$\begin{array}{llll}\text { Issuer: } & \text { Comcast } & \text { Underlying stock: } & \text { Sprint PCS } \\ \text { Security type: } & \text { ZONES } & \text { Offering amount: } & \$ 1.0 \mathrm{~b} . \\ \text { Issue date: } & 10 / 12 / 99 & \text { Maturity date: } & 10 / 15 / 29\end{array}$

Details of acquisition of underlying: In September 1996, Sprint entered into a joint venture with Comcast and other cable companies to provide wireless communications services. In May 1998, Sprint took sole possession of Sprint PCS by issuing Sprint PCS tracking stock to Comcast and its other cable partners.

Issuer:

Liberty Media

Security type:

Issue date:

date: $\quad 11 / 9 / 99$

Underlying stock:

Offering amount:

Maturity date:
Sprint PCS

$\$ 750.0 \mathrm{~m}$.

$11 / 15 / 29$

Details of acquisition of underlying: In September 1996, Sprint entered into a joint venture with TCI (which subsequently became Liberty Media) and other cable companies to provide wireless communications services. In May 1998, Sprint took sole possession of Sprint PCS by issuing Sprint PCS tracking stock to TCI and its other cable partners.

$\begin{array}{llll}\text { Issuer: } & \text { MediaOne } & \text { Underlying stock: } & \text { Vodafone ADRs } \\ \text { Security type: } & \text { PIES } & \text { Offering amount: } & \$ 1.1 \mathrm{~b} \text {. } \\ \text { Issue date: } & 10 / 27 / 99 & \text { Maturity date: } & 11 / 15 / 02\end{array}$

Details of acquisition of underlying: In April 1998, MediaOne sold its domestic wireless business to Airtouch, part of the consideration was Airtouch stock. Airtouch subsequently merged with Vodafone and MediaOne's position in Airtouch was converted to Vodafone ADRs.
Issuer:
Comcast
Underlying stock:
Sprint PCS
Security type:
ZONES
Issue date:
$11 / 2 / 99$
Offering amount:
$\$ 571.4 \mathrm{~m}$.

Details of acquisition of underlying: In September 1996, Sprint entered into a joint venture with Comcast and other cable companies to provide wireless communications services. In May 1998, Sprint took sole possession of Sprint PCS by issuing Sprint PCS tracking stock to Comcast and its other cable partners.

Issuer:

DECS Trust VI

Underlying stock:

MetroMedia

Security type:

DECS

Issue date:

$11 / 12 / 99$

Offering amount: $\quad \$ 394.4 \mathrm{~m}$.

Maturity date: $\quad 11 / 15 / 02$

Details of acquisition of underlying: This trust-based deal was backed by three private shareholders of MetroMedia Fiber Network.

Issuer:

Cox Communications

Underlying stock:

Sprint PCS 
Security type:

Issue date:

PRIZES

$11 / 22 / 99$
Offering amount:

Maturity date:
$\$ 1.1 \mathrm{~b}$.

$11 / 15 / 29$

Details of acquisition of underlying: In September 1996, Sprint entered into a joint venture with Cox Communications and other cable companies to provide wireless communications services. In May 1998, Sprint took sole possession of Sprint PCS by issuing Sprint PCS tracking stock to Cox Communications and its other cable partners.

$\begin{array}{llll}\text { Issuer: } & \text { Roche Holdings } & \text { Underlying stock: } & \text { Genentech Inc. } \\ \text { Security type: } & & \text { Offering amount: } & \$ 1.0 \mathrm{~b} . \\ \text { Issue date: } & 1 / 12 / 00 & \text { Maturity date: } & 1 / 19 / 10\end{array}$

Details of acquisition of underlying: In February 1990, Roche Holdings bought 60 percent of the equity of Genentech for \$2.1 billion.

$\begin{array}{llll}\text { Issuer: } & \text { Alliant Energy } & \text { Underlying stock: } & \text { McLeodUSA } \\ \text { Security type: } & \text { PAY PHONES } & \text { Offering amount: } & \$ 402.5 \mathrm{~m} . \\ \text { Issue date: } & 1 / 26 / 00 & \text { Maturity date: } & 1 / 28 / 30\end{array}$

Details of acquisition of underlying: Alliant bought shares in McLeodUSA for \$30 million between 1993 and 1996. This investment was worth more than \$1.2 billion in January 2000.

$\begin{array}{llll}\text { Issuer: } & \text { NBCI ACES Trust (CNET) } & \text { Underlying stock: } & \text { NBCI Internet, Inc. } \\ \text { Security type: } & \text { TRACES } & \text { Offering amount: } & \$ 101.7 \mathrm{~m} . \\ \text { Issue date: } & 2 / 3 / 00 & \text { Maturity date: } & 2 / 15 / 03\end{array}$

Details of acquisition of underlying: In this trust-based transaction, shares from CNET backed the trust. At the same time, CNET made a secondary offering of shares. NBCi went public in mid-January 2000. In May 1999, CNET acquired shares in NBCi when NBCi was formed by acquiring several internet companies, including CNET's Snap.com.

$\begin{array}{llll}\text { Issuer: } & \text { Cox Communications } & \text { Underlying stock: } & \text { Sprint PCS } \\ \text { Security type: } & \text { PHONES } & \text { Offering amount: } & \$ 275.0 \mathrm{~m} . \\ \text { Issue date: } & 3 / 8 / 00 & \text { Maturity date: } & 3 / 14 / 30\end{array}$

Details of acquisition of underlying: In September 1996, Sprint entered into a joint venture with Cox Communications and other cable companies to provide wireless communications services. In May 1998, Sprint took sole possession of Sprint PCS by issuing Sprint PCS tracking stock to Cox Communications and its other cable partners.

$\begin{array}{llll}\text { Issuer: } & \text { Cox Communications } & \text { Underlying stock: } & \text { Sprint PCS } \\ \text { Security type: } & \text { Exch Sub Debntrs } & \text { Offering amount: } & \text { \$700.0 m. } \\ \text { Issue date: } & 4 / 13 / 00 & \text { Maturity date: } & 4 / 19 / 20\end{array}$

Details of acquisition of underlying: In September 1996, Sprint entered into a joint venture with Cox Communications and other cable companies to provide wireless communications services. In May 1998, Sprint took sole possession of Sprint PCS by issuing Sprint PCS tracking stock to Cox Communications and its other cable partners.

$\begin{array}{llll}\text { Issuer: } & \text { Liberty Media } & \text { Underlying stock: } & \text { Sprint PCS } \\ \text { Security type: } & \text { Sr Exch Debntrs } & \text { Offering amount: } & \$ 810.0 \mathrm{~m} . \\ \text { Issue date: } & 2 / 10 / 00 & \text { Maturity date: } & 2 / 15 / 30\end{array}$

Details of acquisition of underlying: In September 1996, Sprint entered into a joint venture with TCI (which subsequently became Liberty Media) and other cable companies to provide wireless communications services. In May 1998, Sprint took sole possession of Sprint PCS by issuing Sprint PCS tracking stock to TCI and its other cable partners.

Issuer:

Security type: TRACES

Offering date: $11 / 03 / 00$
Underlying:

Offering Amount: $\quad \$ 207.0 \mathrm{~m}$.

Maturity date:
Express Scripts

$11 / 15 / 03$ 
Details of acquisition of underlying: The trust was backed by shares owned by New York Life Insurance Company (NYLIFE), a mutual insurance company. The ACES involved 3 million shares of Express Scripts; in a concurrent secondary offering NYLIFE sold 6 million shares. Until 1992, Express Scripts was entirely owned by NYLIFE.

Issuer: $\quad$ Liberty Media Group

Security type: Convertible Senior Notes

Offering date: $1 / 5 / 01$

Details of acquisition of underlying: In September 1999, Liberty Media received Motorola stock in exchange for its shares of General Instrument. Liberty Media owned 28 percent of General Instrument and was the firm's largest shareholder. In July 1988, an affiliate of TCI (Liberty Mutual's parent at the time) received shares of General Instrument in exchange for certain assets and intellectual property.

$\begin{array}{llll}\text { Issuer: } & \text { Liberty Media Group } & \text { Underlying: } & \text { Viacom } \\ \text { Security type: } & \text { Sr Exch Notes } & \text { Offering Amount: } & \$ 817.7 \mathrm{~m} . \\ \text { Offering date: } & 3 / 5 / 01 & \text { Maturity date: } & 3 / 15 / 31\end{array}$

Details of acquisition of underlying: In early 2001, Viacom acquired Black Entertainment Television (BET)

from Liberty Media. Liberty Media received 15.2 million shares of Viacom. Liberty Media had been a founding investor in BET in 1980. 